\title{
COMPETENCIA INTERNACIONAL EN MATERIA DE EXPEDICIÓN DE CERTIFICADOS SUCESORIOS: A PROPÓSITO DE LA SENTENCIA DEL TJUE 21 JUNIO 2018, VINCENT PIERRE OBERLE, C-20/17
}

\author{
JURISDICTION IN THE ISSUANCE OF SUCCESSION \\ CERTIFICATES: PURPOSE TO THE CJEU JUDGEMENT OF 21ST \\ JUNE 2018, VINCENT PIERRE OBERLE, C-20/17
}

\author{
Ma José Castellanos Ruiz \\ Profesora Ayudante Doctora de Derecho Internacional Privado \\ Universidad Carlos III de Madrid \\ ORCID ID: 0000-0003-1869-4488
}

Recibido: 22.12.2019 / Aceptado: 15.01.2020

DOI: https://doi.org/10.20318/cdt.2020.5199

Resumen: En el Reglamento (UE) 650/2012 no existe una norma específica que regule la competencia en materia de expedición de certificados sucesorios nacionales, incluso no se utiliza nunca la expresión "certificado sucesorio nacional" como tal, sino que los denomina "documentos internos empleados en los Estados miembros para fines similares" a los de los certificados sucesorios europeos. Sin embargo, dicho instrumento internacional sí que contempla una regulación específica relativa a la competencia en materia de expedición de certificados sucesorios europeos (art. 64 Reglamento (UE) 650/2012). Pues bien, ante la "aparente laguna legal" en relación con los certificados sucesorios nacionales, se debe determinar, si dentro del concepto de "totalidad de la sucesión" -que indica el ámbito de aplicación del Reglamento-, se encuentran dichos certificados. En cuyo caso, las normas de competencia del capítulo II del Reglamento sucesorio serían de aplicación a la expedición de los certificados sucesorios nacionales y a los procedimientos relativos a ellos.

En este sentido, la Sentencia del TJUE 21 junio 2018, Vincent Pierre Oberle, C-20/17 y, sobre todo, las Conclusiones del Abogado General Sr. M. Szpunar, han venido a solucionar esta "laguna legal", así como otras cuestiones planteadas de gran importancia, en relación con el asunto concreto que se estaba dirimiendo. Se debe destacar que, con el fallo de la sentencia, se resuelve una cuestión que puede ser relevante para todos los Estados miembros en los que se contempla la posibilidad de que los órganos judiciales expidan certificados sucesorios nacionales.

Palabras clave: Reglamento (UE) 650/2012, certificado sucesorio nacional, certificado sucesorio europeo, competencia internacional, tribunal, notario, resolución, totalidad de la sucesión.

\footnotetext{
Abstract: In Regulation (EU) 650/2012 there is no specific provision that regulates the competence in the issue of national certificates of succession, even the term "national succession of certificate" is never used as such, but rather calls them "internal documents used for similar purposes in the Member States" to those of European Certificates of Succession. However, this international instrument contemplates a specific regulation governing the competence in the issue of European Certificate of Succession (art. 64 Regulation (EU) 650/2012). Well, given the "apparent legal loophole" in relation to national certificates of succession, it must be determined, if within the concept "succession as a whole" -which indicates the scope of the Regulation-, such certificates are found. In which case, the jurisdiction rules
} 
of Chapter II of this Regulation would apply to the issuance of national certificates of succession and the procedures related to them.

In this regard, the CJEU Judgement of 21st June 2018, Vincent Pierre Oberle, C-20/17, and, above all, the Conclusions of the Advocate General Mr. M. Szpunar, have come to solve this "legal loophole", as well as others issues raised of great importance, in relation to the specific issue that was being settled. This case, on the other hand, involves the resolution of an issue which could be relevant to all Member States where provision is made for judicial authorities to issue national certificates of succession

Keywords: Regulation (EU) 650/2012, national certificate of succession, European Certificate of Succession, international jurisdiction, court, notary, resolution, succession as a whole.

Sumario: I. Introducción. II. Competencia general para resolver sobre la totalidad de la sucesión: el art. 4 del Reglamento (UE) 650/2012. 1. Concepto de "tribunal". 2. Concepto de "resolver sobre la totalidad de la sucesión". 3. Concepto de "resolución". 4. El art. 4 del Reglamento (UE) 650/2012 en el contexto de otras normas del capítulo II de dicho Reglamento. III. Competencia internacional en materia de expedición de certificados sucesorios europeos. 1. El art. 64 del Reglamento (UE) 650/2012. 2. Relación entre el art. 64 y el art. 4 del Reglamento (UE) 650/2012. IV. Competencia internacional en materia de expedición de certificados sucesorios nacionales. 1. Análisis de la Sentencia del TJUE 21 junio 2018, Vincent Pierre Oberle, C-20/17. A) Hechos y cuestión prejudicial. B) Los certificados sucesorios nacionales como objeto del ámbito de aplicación del Reglamento (UE) 650/2012 C) La competencia en materia de expedición de los certificados sucesorios nacionales: el art. 4 del Reglamento (UE) 650/2012. a) Postura de las partes. b) Interpretación teleológica del Abogado General en las Conclusiones de la sentencia. c) Interpretación histórica del Abogado General en las Conclusiones de la sentencia. d) Conclusiones. 2. Implicaciones para los Estados miembros.

\section{Introducción}

1. La Sentencia del TJUE de 21 junio 2018, Vincent Pierre Oberle, C-20/17, responde a la tercera cuestión prejudicial planteada por un órgano juridiccional de un Estado miembro solicitando una interpretación de las disposiciones del Reglamento (UE) núm. 650/2012 del Parlamento Europeo y del Consejo, de 4 de julio de 2012, relativo a la competencia, la ley aplicable, el reconocimiento y la ejecución de las resoluciones, a la aceptación y la ejecución de los documentos públicos en materia de sucesiones mortis causa y a la creación de un certificado sucesorio europeo ${ }^{1}$.

La cuestión prejudicial planteada por el órgano jurisdiccional remitente se refiere a la relación del Reglamento (UE) 650/2012 con las disposiciones nacionales que regulan las sucesiones. De manera que el Kammergericht Berlin (Tribunal Superior Regional de lo Civil y Penal de Berlín) solicita que se determine si el art. 4 del Reglamento 650/2012 atribuye también competencia con respecto a los procedimientos de expedición de los certificados sucesorios nacionales ${ }^{2}$. Esto tendría como consecuencia que los Estados miembros no podrían aplicar normas internas de competencia judicial internacional diferentes a las previstas por el Reglamento (UE) 650/20123.

\footnotetext{
${ }^{1}$ Para los Estados miembros que son parte en el mismo, desde el 17 de agosto de 2015 es de aplicación en materia sucesoria el Reglamento (UE) núm. 650/2012 del Parlamento Europeo y del Consejo, de 4 de julio de 2012 (DOUE núm. L 201, 27 julio 2012), relativo a la competencia, la ley aplicable, el reconocimiento y la ejecución de las resoluciones, a la aceptación y la ejecución de los documentos públicos en materia de sucesiones mortis causa y a la creación de un certificado sucesorio europeo. En las referencias posteriores que se hagan en relación con dicho instrumento internacional, éste será denominado Reglamento (UE) 650/2012. Vid. STJUE 21 junio 2018, Vincent Pierre Oberle, C-20/17, ECLI:EU:C:2018:485.

${ }^{2}$ STJUE 21 junio 2018, Vincent Pierre Oberle, C-20/17, ECLI:EU:C:2018:485, apartado 28.

${ }^{3}$ Conclusiones del Abogado General Sr. M. Szpunar, presentadas el 22 de febrero de 2018, Vincent Pierre Oberle, C-20/17, ECLI:EU:C:2018:89, apartado 2.
} 
Tal y como señala en sus Conclusiones el Abogado General Sr. M. Szpunar, la cuestión prejudicial es extraordinariamente compleja y la relevancia práctica de esta sentencia es mucho mayor que la que pueda derivarse del asunto Mahnkopf $f^{4}$. En este último caso se hacía referencia a una norma singular del Derecho alemán, mientras que en el asunto Vincent Pierre Oberle se resuelve una cuestión que puede ser relevante para todos los Estados miembros en los que se ha estipulado la posibilidad de que los órganos jurisdiccionales expidan certificados sucesorios nacionales ${ }^{5}$. Además de otras implicaciones sobre los Estados miembros derivados de la intrepretación que se realiza de otros preceptos, como es el caso del art. 64 del Reglamento (UE) 650/2012, que recoge la competencia en materia de expedición de certificados sucesorios europeos.

Existe otra sentencia posterior en cierto modo relacionada con la sentencia del asunto Vincent Pierre Oberle. Se trata de la sentencia del TJUE 23 mayo 2019, WB c Notariusz Przemystawa Bac, C-658/17, en la que la cuestión prejudicial que se plantea es si los notarios polacos, encargados de otorgar escrituras de declaración de herederos, ejercen funciones jurisdiccionales ${ }^{6}$. Sin embargo, para responder a la cuestión planteada, el Abogado General Sr. Y. Bot utiliza la interpretación de los diversos conceptos de las Conclusiones del Abogado General en el asunto Vincent Pierre Oberle, realizando determinadas precisiones terminológicas al caso concreto ${ }^{7}$. Por lo que, se aludirá a la sentencia de 23 de mayo de 2019, cuando se aborden aspectos que son tratados en dicha sentencia; si bien es en la sentencia y, sobre todo, en las Conclusiones del Abogado General Mr. Szpunar al asunto Vincent Pierre Oberle, donde las interpretaciones realizadas contribuyen en mayor medida a una correcta aplicación del Reglamento sucesorio.

2. Tanto en los argumentos utilizados para llegar al fallo de la sentencia STJUE 21 junio 2018, Vincent Pierre Oberle, C-20/17, como en las Conclusiones del Abogado General Sr. M. Szpunar, se procede a realizar una interpretación autónoma de conceptos especialmente relevantes para una correcta aplicación del Reglamento (UE) 650/2012.

Por ello y en aras de una mejor comprensión del fallo de la sentencia, que resuelve si la norma de competencia general del art. 4 del Reglamento (UE) 650/2012 es también de aplicación a la expedición de los certificados sucesorios nacionales, se ha dividido el presente estudio en tres apartados. En primer lugar, se procede al análisis de la competencia general para pronunciarse sobre la totalidad de la sucesión, recogida en el art. 4 del Reglamento (UE) 650/2012; así como su relación con otras normas del capítulo II, concretamente con el art. 13 de dicho instrumento internacional. Después se van a señalar los criterios de competencia internacional en materia de expedición de los certificados sucesorios europeos contemplados en el art. 64 del Reglamento (UE) 650/2012; y la relación entre este precepto y el art. 4 del Reglamento sucesorio. Ambos apartados son fundamentales para comprender tanto la interpretación literal, como la interpretación sistemática, que realiza el Abogado General Sr. M. Szpunar en sus Conclusiones sobre el asunto Vincent Pierre Oberle ${ }^{8}$.

Por último, se analizará la respuesta a la cuestión prejudicial planteada en la Sentencia del TJUE 21 junio 2018, Vincent Pierre Oberle, C-20/17, que no es otra que la determinación de la competencia internacional en materia de expedición de certificados sucesorios nacionales. Así como, las consecuencias que tiene el fallo de la sentencia sobre el resto de Estados miembros en los que es de aplicación el Reglamento (UE) 650/2012.

\footnotetext{
${ }^{4}$ STJUE 1 marzo 2018, Mahnkopf, C-558/16, ECLI:EU:C:2018:138.

${ }_{5}^{5}$ Conclusiones del Abogado General Sr. M. Szpunar, presentadas el 22 de febrero de 2018, Vincent Pierre Oberle, C-20/17, ECLI:EU:C:2018:89, apartado 3.

${ }^{6}$ STJUE 23 mayo 2019, WB c Notariusz Przemysława Bac, C-658/17, ECLI:EU:C:2019:444.

${ }^{7}$ Conclusiones del Abogado General Sr. Y. Bot, presentadas el 28 de febrero de 2019, WB c. Notariusz Przemystawa Bac, C-658/17, ECLI:EU:C:2019:166, apartado 81.

${ }^{8}$ Conclusiones del Abogado General Sr. M. Szpunar, presentadas el 22 de febrero de 2018, Vincent Pierre Oberle, C-20/17, ECLI:EU:C:2018:89, apartados 57-93.
} 


\section{Competencia general para resolver sobre la totalidad de la sucesión: el art. 4 del Reglamento (UE) 650/2012}

3. La competencia judicial internacional del Reglamento (UE) 650/2012 en materia sucesoria está regulada en el capítulo II, concretamente en los arts. 4 a $19^{9}$. El Considerando (20) establece los aspectos básicos de las normas de competencia judicial internacional en materia sucesoria ${ }^{10}$.

El Reglamento (UE) 650/2012 debe respetar los distintos sistemas nacionales para sustanciar sucesiones que se aplican en los distintos Estados miembros ${ }^{11}$. Sin embargo, el Reglamento sucesorio europeo no armoniza ninguna normativa nacional de los Estados miembros, sino que, tal y como precisa K.-W. LANGE, crea un DIPr. sucesorio europeo de nuevo cuño ${ }^{12}$.

En este sentido, cada Estado miembro regula de manera diferente la sucesión mortis causa desde el punto de vista de las autoridades competentes en esta materia. Algunos Estados miembros cuentan con un sistema de competencia basado en órganos judiciales que ejercitan poderes jurisdiccionales. Mientras que otros Estados miembros disponen de un sistema legal basado, fundamentalmente, en la intervención de órganos públicos no judiciales que no ejercitan poderes jurisdiccionales o de órganos judiciales pero que operan sin poderes jurisdiccionales, es decir, en régimen de jurisdicción voluntaria ${ }^{13}$. Sin embargo, en algunos Estados miembros también es posible que los notarios o las oficinas de registro ejerzan funciones jurisdiccionales en determinados supuestos; así como los notarios y los profesionales del derecho pueden ejercer dichas funciones en una sucesión determinada, por delegación de un tribunal ${ }^{14}$.

4. La norma de competencia general en materia sucesoria se recoge en el art. 4 del Reglamento (UE) 650/2012, que establece que los tribunales del Estado miembro en el que el causante tuviera su residencia habitual en el momento del fallecimiento tendrán competencia para pronunciarse o resolver sobre la totalidad de la sucesión ${ }^{15}$.

Además, del apartado en el que se inserta el artículo 4 del Reglamento (UE) 650/2012 se desprende que dicho precepto regula la determinación de la competencia general de los tribunales de los Estados miembros; mientras que el reparto de las competencias en el plano interno se establece según las reglas nacionales, de conformidad con el artículo 2 del Reglamento sucesorio ${ }^{16}$.

5. Pero, para poder conocer si es de aplicación el art. 4 del Reglamento (UE) 650/2012 a la determinación de la competencia para la expedición de los certificados sucesorios nacionales, en el asunto Vincent Pierre Oberle, se debe responder a las siguientes cuestiones: ¿qué se entiende por "tribunal"?; ¿qué alcance tiene el concepto de "resolver sobre la totalidad de la sucesión"?; y por lo tanto, ¿qué se incluye dentro del término "resolución"?

Dado que la interpretación literal del art. 4, que hace el Abogado General Sr. M. Szpunar en sus Conclusiones, no otorga una respuesta unívoca a la cuestión planteada, este procede a comparar el art. 4 con el art. 13 del Reglamento (UE) 650/2012, que también será explicado a continuación ${ }^{17}$.

9 J. Carrascosa GonzÁlez, El Reglamento sucesorio europeo 650/2012 de 4 de julio de 2012. Análisis crítico, Rapid Centro Color, Murcia, 2019, p. 119.

${ }^{10}$ E. Castellanos Ruiz, "Sucesión Hereditaria. El Reglamento Sucesorio Europeo", en A.-L. Calvo Caravaca/J. CarrasCosa GonzÁlez (dirs.), Derecho Internacional Privado, Volumen II, Comares, Granada, 2018, p. 598.

${ }^{11}$ Considerando (20) Reglamento (UE) 650/2012.

${ }^{12}$ K.-W. LANGE, "Die geplante Harmonisierung des Internationalen Erbrechts in Europa", Zeitschrift für Vergleichende Rechtswissenschaft, 2011, pp. 426-437; J. CARRASCOSA GONZÁLEZ, "Reglamento sucesorio europeo y actividad notarial", Cuadernos de Derecho Transnacional, vol. 6, $\mathrm{n}^{\circ}$ 1, marzo 2014, p. 9.

13 J. CARrascosa GonzÁlez, "Reglamento sucesorio europeo y actividad notarial", Cuadernos de Derecho Transnacional, vol. $6, \mathrm{n}^{\mathrm{o}} 1$, marzo 2014, p. 13.

${ }_{14}$ Considerando (20) Reglamento (UE) 650/2012.

${ }_{15}$ STJUE 21 junio 2018, Vincent Pierre Oberle, C-20/17, ECLI:EU:C:2018:485, apartado 34.

${ }^{16}$ STJUE 21 junio 2018, Vincent Pierre Oberle, C-20/17, ECLI:EU:C:2018:485, apartado 34.

${ }^{17}$ El análisis del art. 4 del Reglamento (UE) 650/2012 en el contexto de otras normas del capítulo II de dicho instrumento forma parte de la interpretación sistemática del art. 4 que realiza el Abogado General en sus Conclusiones. Vid. Conclusiones del Abogado General Sr. M. Szpunar, presentadas el 22 de febrero de 2018, Vincent Pierre Oberle, C-20/17, ECLI:EU:C:2018:89, apartados 78-85. 


\section{Concepto de "tribunal"}

6. En virtud del art. 3.2 del Reglamento (UE) 650/2012 se pueden distinguir dos categorías dentro del término "tribunal": por un lado, los órganos judiciales (Gericht/judicial authority/gerechtelijke autoriteit); y, por otro lado, las demás autoridades y profesionales del derecho. Las dos categorías son objeto de precisiones distintas dentro del Reglamento (UE) 650/2012, aunque ambas se han incluido dentro del concepto de "tribunal" para respetar los diferentes sistemas legales con los que cuentan los Estados miembros para regular la sucesión ${ }^{18}$. En ciertos Estados miembros, los notarios desempeñan un papel fundamental en la liquidación de la sucesión, mientras que en otros Estados miembros los funcionarios públicos participan en las distintas etapas de dicha liquidación. Es más, un abogado puede ser llamado a realizar esta función si lo solicita un tribunal, como ocurre en Suecia o en Finlandia ${ }^{19}$.

Además, el Reglamento sucesorio utiliza otros conceptos junto con la noción de "jurisdicción". En relación con el certificado sucesorio europeo, el art. 64 distingue a los "tribunales" de otras "autoridades" que son igualmente competentes en materia sucesoria; cuestión que será analizada en el apartado del certificado sucesorio europeo ${ }^{20}$.

Por otro lado, el art. 72 utiliza un concepto distinto, puesto que este precepto reserva a las "autoridades judiciales" la posibilidad de conocer por la vía de los recursos contra las decisiones relativas a los certificados sucesorios ${ }^{21}$. Este precepto no será estudiado por no estar directamente relacionado con el objeto de estudio del presente trabajo.

7. Por esta razón, el concepto de "tribunal" del Reglamento (UE) 650/2012, debe entenderse en un sentido amplio, de modo que no solo abarque a los órganos judiciales en sentido propio, que ejercen funciones jurisdiccionale ${ }^{22}$; sino también a los notarios o a las oficinas del registro en algunos Estados miembros, que, en determinados supuestos, ejercen tal tipo de funciones; así como los notarios y profesionales del Derecho que, en algunos Estados miembros, ejercen tales funciones jurisdiccionales en una sucesión determinada, por delegación de un tribunal.

Por lo tanto, a efectos del Reglamento, un "tribunal" puede ser: (a) Un órgano judicial que desarrolla funciones jurisdiccionales en el sector sucesorio; (b) Una autoridad no judicial de un Estado miembro que desarrolla, igualmente, funciones jurisdiccionales en el sector sucesorio según la Ley de dicho Estado miembro; (c) Un abogado o un notario u otra autoridad o profesional del Derecho, que ejerza funciones jurisdiccionales por delegación de un tribunal de un Estado miembro participante en el Reglamento (UE) 650/2012 23 .

En este sentido, el art. 3.2 define, a los efectos del Reglamento el término "tribunal" como todo órgano judicial y todas las demás autoridades y profesionales del Derecho con competencias en materia de sucesiones que (a) ejerzan funciones jurisdiccionales, o que (b) actúen por delegación de poderes de un órgano judicial, o que (c) actúen bajo su control, siempre que tales autoridades y profesionales del Derecho ofrezcan garantías en lo que respecta a (d) su imparcialidad y (e) al derecho de las partes a ser oídas, y que sus resoluciones, dictadas con arreglo al Derecho del Estado miembro en el que actúan, (f)

${ }^{18}$ P. Wautelet, “Article 3: Definitions” en A. Bonomi/P. Wautelet/I. Pretelli/A. Öztürk, Le droit européen des successions. Commentaire du Règlement $n^{\circ}$ 650/2012 du 4 juillet 2012, 2a ed., Bruylant, Bruxelles, 2016, p. 171.

19 A.-M.-E. Giuliano, "De Erfrechtverordenig: één bevoegde autoriteit en één toepasselikj recht", FPR, 2013, p. 69; P. Wautelet, "Article 3: Definitions" en A. Bonomi/P. Wautelet/I. Pretelli/A. Öztürk, Le droit européen des successions. Commentaire du Règlement $n^{o}$ 650/2012 du 4 juillet 2012, $2^{\mathrm{a}}$ ed., Bruylant, Bruxelles, 2016, pp. 171-172.

${ }^{20}$ P. Wautelet, “Article 3: Definitions" en A. Bonomi/P. Wautelet/I. Pretelli/A. ÖZtürk, Le droit européen des successions. Commentaire du Règlement $n^{\circ}$ 650/2012 du 4 juillet 2012, 2a ed., Bruylant, Bruxelles, 2016, p. 172.

${ }^{21}$ P. Wautelet, “Article 3: Definitions” en A. Bonomi/P. Wautelet/I. Pretelli/A. Öztürk, Le droit européen des successions. Commentaire du Règlement n ${ }^{o}$ 650/2012 du 4 juillet 2012, 2a ed., Bruylant, Bruxelles, 2016, p. 172.

${ }^{22}$ Como ha destacado O. FerACI, el Reglamento acoge un concepto muy extenso de "tribunal" que no se circunscribe exclusivamente a los "órganos judiciales (O. FERACI, "La nuova disciplina europea della competenza giurisdizionale in materia di successioni mortis causa", Cuadernos de Derecho Transnacional, vol. 5, n 2, octubre 2013, pp. 291-314).

${ }^{23}$ J. CARrascosa GonzÁlez, "Reglamento sucesorio europeo y actividad notarial", Cuadernos de Derecho Transnacional, vol. $6, \mathrm{n}^{\mathrm{o}} 1$, marzo 2014, pp. 13-14. 
puedan ser objeto de recurso o revisión ante un órgano judicial, y $(\mathrm{g})$ tengan fuerza y efectos análogos a los de la resolución de un órgano judicial sobre la misma materia ${ }^{24}$.

8. Todos los tribunales tal y como se definen en el presente Reglamento deben estar vinculados por las normas de competencia establecidas en el mismo ${ }^{25}$. Ahora bien, Reino Unido e Irlanda (Considerando 82), así como Dinamarca (Considerando 83) no están obligados por el Reglamento 620/2012, dado que no han participado en su adopción y, por tanto, no quedan sujetos a su aplicación, ni vinculados por el Reglamento ${ }^{26}$.

9. Concepto de "las demás autoridades y profesionales del Derecho". Así pues, dentro del concepto de "tribunal" el Reglamento sucesorio los incluye, pero siempre que ejerzan funciones jurisdiccionales, en virtud de lo establecido en el art. 3.2 del Reglamento sucesorio.

No obstante, el término "tribunal" no debe incluir a las autoridades no judiciales de un Estado miembro que, en virtud del Derecho nacional, están facultadas para sustanciar sucesiones, como los "notarios" en la mayoría de los Estados miembros en aquellos casos en los que, como ocurre habitualmente, no ejercen funciones jurisdiccionales ${ }^{27}$. Por lo que el Reglamento no afecta a las competencias que los Estados miembros atribuyan a los notarios en materia de sucesiones ${ }^{28}$.

Por tanto, su inclusión o no en el término "tribunal" dependerá de si ejercen, en el Estado miembro concreto "función jurisdiccional". Esta hipótesis será poco frecuente. La mayoría de las funciones realizadas por los notarios de los Estados donde no rige el common law no son consideradas tareas de naturaleza jurisdiccional. Se trata normalmente de la redacción de un testamento o de un pacto sucesorio; de consejos realizados en materia de planificación sucesoria; o de la redacción de un acto de notoriedad o de herencia. En estas funciones, el notario no puede ser asimilado a un tribunal, por lo que no estarán vinculados por las normas de competencia del Reglamento (UE) 650/2012. Así M. DutTA señala que en este sentido el notario alemán "raramente" será considerado un tribunal en el sentido del Reglamento ${ }^{29}$.

10. En cuanto al concepto de "funciones jurisdiccionales" realizadas por autoridades no judiciales es desarrollado en la sentencia y las Conclusiones del Abogado General del asunto WB c Notariusz Przemysława Bac. En este caso, la cuestión prejudicial que se plantea es si los notarios polacos, encargados de otorgar escrituras de declaración de herederos, ejercen funciones jurisdiccionales ${ }^{30}$. Precisa-

${ }^{24}$ M. Weller, "Scope and Definitions", en A.-L. Calvo Caravaca/A. Davi/H.-P. Mansel (eds.), The EU Succession Regulation: a commentary, Cambridge University Press, Cambridge, 2016, p. 122.

${ }^{25}$ Considerando (20) Reglamento (UE) 650/2012.

${ }^{26}$ Vid. A. Davì, "Introduction", en A.-L. Calvo Caravaca/A. Davì/H.-P. Mansel (eds.), The EU Succession Regulation: a commentary, Cambridge University Press, Cambridge, 2016, pp. 11-18.

${ }^{27}$ Considerando (20) Reglamento (UE) 650/2012.

${ }^{28}$ Considerando (21) Reglamento (UE) 650/2012.

${ }^{29}$ A. Dutta, "EuErbVO”, Münchener Kommentar, Internationales Privatrecht I, 6º Ed., C.H. Beck, München, 2015, p. 16; P. Wautelet, “Article 3: Definitions” en A. Bonomi/P. Wautelet/I. Pretelli/A. Öztürk, Le droit européen des successions. Commentaire du Règlement $n^{\circ}$ 650/2012 du 4 juillet 2012, 2a ed., Bruylant, Bruxelles, 2016, p. 175.

${ }^{30}$ Los hechos del caso son los siguientes. La recurrente, WB, era una de las partes intervinientes en el procedimiento dirigido a la obtención de una escritura de declaración de herederos relativo a la sucesión de su padre. El padre, de nacionalidad polaca, falleció el 6 de agosto de 2016 y tenía residencia habitual en Polonia. Dicha escritura fue otorgada el 21 de octubre de 2016 por un notario polaco, de conformidad con el Derecho polaco. Al ser el causante un empresario que desarrollaba una actividad económica en la región fronteriza germano-polaca, la recurrente quiso averiguar si había en Alemania alguna entidad bancaria que poseyera fondos depositados por su padre y, de ser así, cuál era el importe que podía incluirse en la masa hereditaria. Pues bien, en las cuestiones prejudiciales planteadas es si la escritura de declaración de herederos constituye una certificación, cuyo formulario figura en el anexo 1 del Reglamento de Ejecución núm. 1329/2014 Comisión, de 9 de diciembre de 2014 (DOUE núm L), acreditativa de que dicha escritura constituye una resolución en materia de sucesiones en el sentido del art. 3.1.g) del Reglamento (UE) 650/2012; o bien, constituye un documento público en materia de sucesiones en el sentido del art. 3.1.i), del Reglamento . $^{\circ}$ 650/2012, cuyo formulario II es el establecido en el anexo 2 del citado Reglamento. Para resolver esta cuestión, se debe aclarar por tanto si los notarios polacos, que formalizan escrituras de declaración de herederos, ejercen funciones jurisdiccionales (Conclusiones del Abogado General Sr. Y. Bot, presentadas el 28 de febrero de 2019, WB c. Notariusz Przemystawa Bac, C-658/17, ECLI:EU:C:2019:166, apartados 29-41). Vid. Reglamento de Ejecución (UE) núm. 1329/2014 de la Comisión, de 9 de diciembre de 2014 (DO núm. L 35916 diciembre 2014), por el que se establecen los formularios mencionados en el Reglamento (UE) núm. 650/2012 del Parlamento Europeo y del Consejo relativo a la competencia, la ley aplicable, el recono- 
mente el Abogado General señala que los conceptos de "resolución" y de "funciones jurisdiccionales" están íntimamente relacionados, como señala el Considerando (22) del Reglamento (UE) 650/2012 $2^{31}$. En él se establece que, "cuando los notarios ejercen funciones jurisdiccionales, están vinculados por las normas de competencia, y las resoluciones que dicten deben circular de acuerdo con las disposiciones sobre reconocimiento, fuerza ejecutiva y ejecución de resoluciones"; $\mathrm{y}$, además, añade que, "cuando los notarios no ejercen funciones jurisdiccionales, no están vinculados por las normas de competencia, y los documentos públicos que expidan deben circular de acuerdo con las disposiciones sobre estos". En definitiva, si se considera que los notarios polacos no ejercen funciones jurisdiccionales, los documentos públicos que emiten circulan más fácilmente que una resolución.

En este sentido, el Abogado General Sr. Y. Bot para determinar si los notarios pueden ser considerados "tribunales", por ejercer funciones jurisdiccionales, utiliza la interpretación del concepto "resolución", de las Conclusiones del Abogado General en el asunto Vincent Pierre Oberle -que será estudiado posteriomente-; pero realizando determinadas precisiones terminológicas al caso concreto, porque en el asunto Vincent Pierre Oberle, la cuestión sucesoria planteada se refiere a las actuaciones de los "órganos judiciales" 32

De dicha interpretación del concepto de "resolución" de asunto Vincent Pierre Oberle, Abogado General Sr. Y. Bot en el asunto WB c Notariusz Przemysława Bac, señala que con la expresión "funciones jurisdiccionales" se está haciendo referencia tanto a los procedimientos contenciosos como a los procedimientos de jurisdicción voluntaria, siempre que estos últimos no dependan únicamente de la voluntad de las partes ${ }^{33}$. No se debe considerar que el TJUE en el asunto Vincent Pierre Oberle haya pretendido modificar el concepto de "funciones jurisdiccionales", haciéndolo extensivo a los documentos que tienen por efecto registrar una manifestación de voluntad privada ${ }^{34}$.

Por lo tanto, el Sr. Y. Bot concluye que de dicha sentencia relativa a un procedimiento de jurisdicción voluntaria no se puede deducir que las autoridades no judiciales que expiden certificados sucesorios, a falta de oposición, dictan resoluciones como un tribunal en el sentido del art. 3.1.g) del Reglamento (UE) 650/2012 35 .

Teniendo en cuentas dichas interpretaciones y las funciones que ejercía el notario polaco en el asunto WB c Notariusz Przemystawa Bac, el TJUE consideró que los notarios polacos, que redactan un documento a solicitud de todas las partes del procedimiento notarial, no ejercían funciones jurisdiccionales, así que no podía ser considerado "tribunal", en el sentido del Reglamento (UE) 650/2012. Eso sí, constituye un "documento público", cuya expedición puede ir acompañada del formulario que figura en el anexo 2 del Reglamento de Ejecución (UE) núm. 1329/2014 de la Comisión, de 9 de diciembre de 2014, por el que se establecen los formularios en el Reglamento (UE) 650/2012 (art. 59.1. párrafo segundo) ${ }^{36}$.

11. Por otro lado, se podría contemplar también la posibilidad de que el notario pudiera actuar por delegación en el sentido del art. 3.2 del Reglamento 650/2012, puesto que cuando éste procede a la liquidación de una sucesión, esta tarea es encargada por un tribunal. Efectivamente, en algunos Estados miembros como son Francia y Bélgica, la intervención del notario en la liquidación de una sucesión puede hacerse mediante la designación expresa de un tribunal. Aunque no será fácil en ocasiones determinar si el notario que es llamado a intervenir en el marco de una liquidación-partición lo hace en virtud de una delegación de poderes o bajo el control de un tribunal, ni si el notario cumple con el resto de condiciones señaladas por el art. 3.237. En algunos Estados miembros, se solicita la intervención de un notario para

\footnotetext{
cimiento y la ejecución de las resoluciones, a la aceptación y la ejecución de los documentos públicos en materia de sucesiones mortis causa y a la creación de un certificado sucesorio europeo.

${ }^{31}$ Conclusiones del Abogado General Sr. Y. Bot, presentadas el 28 de febrero de 2019, WB c. Notariusz Przemystawa Bac, C-658/17, ECLI:EU:C:2019:166, apartado 60.

32 Ibidem, apartado 81.

${ }^{33}$ Idem, apartado 86.

${ }^{34}$ Idem, apartado 87.

${ }^{35}$ Idem, apartado 89.

${ }^{36}$ STJUE 23 mayo 2019, WB c Notariusz Przemystawa Bac, C-658/17, ECLI:EU:C:2019:444, apartado 73.

${ }^{37}$ P. Wautelet, "Article 3: Definitions" en A. Bonomi/P. Wautelet/I. Pretelli/A. ÖZtürk, Le droit européen des successions. Commentaire du Règlement no 650/2012 du 4 juillet 2012, 2a ed., Bruylant, Bruxelles, 2016, pp. 175-176.
} 
intervenir judicialmente en tareas concretas en el marco de la sucesión. Este es el caso de Alemania, donde los notarios intervienen cuando se trata de acciones para el reparto de la comunidad de bienes ${ }^{38}$.

En definitiva, teniendo en cuenta la práctica habitual en la mayor parte de los Estados miembros, los notarios no responderán nada más que excepcionalmente a las exigencias establecidas en el art. 3.2 del Reglamento de sucesiones. En estos Estados miembros, los notarios no serán considerados "tribunales". Por lo tanto, los notarios no estarán vinculados por las normas de competencia del Reglamento y no dictarán decisiones que sean susceptibles de ser reconocidas en virtud de dicho texto. En estos casos, las partes podrían confiar a los notarios de un Estado miembro una tarea de liquidación-partición de una sucesión cuando los tribunales de ese Estado miembro no fuesen competentes en virtud del Reglamento, aunque dicha función sólo podría tener el carácter de amigable ${ }^{39}$. Tal y como señala P. WAUTELET cabe plantearse la pregunta de si la intervención de los notarios en estos casos sería oportuna o adecuada.

12. Pero son los Estados miembros los que, en virtud del art. 79.1 del Reglamento (UE) 650/2012, tienen que comunicar a la Comisión si los notarios u otros profesionales, u otras autoridades no judiciales ejercen funciones jurisidiccionales, cumpliendo así con los requisitos del art. 3.2 del Reglamento sucesorio. En este sentido, España ha hecho una comunicación al respecto, mientras que Francia y Alemania no la han realizado. Este tema será tratado con mayor detalle en el último apartado, el de la competencia internacional en materia de expedición de certificados sucesorios nacionales.

Sin embargo, esta declaración, comunicación o notificación no es definitiva, así lo ha establecido el TJUE en en el asunto WB c Notariusz Przemystawa Bac. En la sentencia y en las Conclusiones del Abogado General Sr. Y. Bot se establece que la falta de notificación a que se refiere el artículo 3.2 en su párrafo segundo del Reglamento sucesorio, por parte de Polonia, en relación al ejercicio por los notarios de funciones jurisdiccionales, no tiene carácter definitivo. Esto significa que si los Estados no notifican que sus notarios son "otras autoridades" en el sentido del art. 3.2 Reglamento sucesorio, no implica que éstos no puedan ser considerados "tribunal" y estar sometidos a las normas de competencia internacional del mismo. El Abogado General señala que dicha calificación debe ser realizada por el órgano jurisdiccional nacional en cuestión, de forma autónoma, de manera que en cualquier caso la declaración realizada por la autoridad nacional competente no vincula a dicho órgano jurisdiccional; y eso se podría extrapolar a los casos de ausencia de declaración ${ }^{40}$.

13. Concepto de "órgano judicial". Pues bien, como se ha podido constatar, hasta la sentencia del asunto Vincent Pierre Oberle, la mayoría de la literatura sobre el concepto de "tribunal" se ha centrado en establecer cuáles podrían ser "las demás autoridades y profesionales del Derecho", que en virtud del art. 3.2 del Reglamento sucesorio, podían ejercer funciones jurisdiccionales. Sin embargo, el Abogado General en sus Conclusiones sobre dicho asunto pretende determinar si dentro del concepto de "tribunal" está incluído "todo órgano judicial" o únicamente "los órganos judiciales que ejercen funciones jurisdiccionales" ${ }^{1}$.

El Considerando (20), en su segunda frase, señala que el concepto «tribunal» se debe dotar de un sentido amplio, de modo que abarque "los órganos judiciales en sentido propio, que ejercen funciones jurisdiccionales" y también otros sujetos que ejerzan las funciones jurisdiccionales en algunos

${ }^{38}$ P. Wautelet, “Article 3: Definitions” en A. Bonomi/P. Wautelet/I. Pretelli/A. ÖZtürk, Le droit européen des successions. Commentaire du Règlement $n^{\circ}$ 650/2012 du 4 juillet 2012, 2a ed., Bruylant, Bruxelles, 2016, p. 176.

${ }^{39} \mathrm{Si}$ los tribunales de ese Estado miembro no tuviesen competencia, los notarios no podrían expedir un certificado sucesorio europeo, pues no son considerados "tribunales" (P. Wautelet, "Article 3: Definitions" en A. Bonomi/P. Wautelet/I. Pretelli/A. Öztürk, Le droit européen des successions. Commentaire du Règlement $n^{\circ}$ 650/2012 du 4 juillet 2012, $2^{\mathrm{a}}$ ed., Bruylant, Bruxelles, 2016, p. 178). Aunque como se verá al analizar los certficados sucesorios europeos, si el Estado miembro, en virtud del art. 78.1.c), comunica a la Comisión que los notarios son "otra autoridad" para la expedición de los certificados sucesorios europeos, podrían realizarlos aunque no hubiese foro de competencia judicial internacional, pues en virtud de su derecho interno son competentes para sustanciar sucesiones mortis causa (art. 64.b)). Si bien sobre este tema no existe una postura unánime al respecto, generándose un debate, tal y como se podrá comprobar.

40 Vid. STJUE 23 mayo 2019, WB c Notariusz Przemysława Bac, C-658/17, ECLI:EU:C:2019:444, apartados 40-49; Conclusiones del Abogado General Sr. Y. Bot, presentadas el 28 de febrero de 2019, WB c. Notariusz Przemystawa Bac, C-658/17, ECLI:EU:C:2019:166, apartados 64-69.

${ }^{41}$ Conclusiones del Abogado General Sr. M. Szpunar, presentadas el 22 de febrero de 2018, Vincent Pierre Oberle, C-20/17, ECLI:EU:C:2018:89, apartados 58-64. 
$\operatorname{asuntos}^{42}$. En consecuencia, se puede afirmar que "el órgano que formalmente integra la estructura de la jurisdicción de un determinado Estado miembro", pero que no ejerce funciones jurisdiccionales en un procedimiento concreto, no puede ser considerado un "tribunal" en el sentido del Reglamento sucesorio $^{43}$. En mi opinión, esta es la solución que debería haber sido adoptada por el Abogado General en sus Conclusiones, puesto que para que "las demás autoridades y profesionales del Derecho" puedan ser consideradas "tribunales" es necesario que cumplan funciones jurisdiccionales.

14. Sin embargo, el Abogado General no está de acuerdo con esta interpretación restrictiva del concepto de "tribunal", puesto que el art. 3.2 del Reglamento (UE) 650/2012 no aclara si el concepto de "tribunal" abarca "todo órgano judicial" ${ }^{4}$. En su opinión, tampoco del Considerano (20) se puede concluir de forma unívoca que este concepto no incluye "los órganos judiciales en sentido propio" que no ejerzan funciones jurisdiccionales en un procedimiento determinado ${ }^{45}$.

Así pues, el Abogado General concluye que de la interpretación literal del concepto de "tribunal" no se puede determinar que el art. 4 del Reglamento (UE) 650/2012 "atribuya la competencia exclusivamente respecto de los procedimientos en los que el órgano judicial ejerce funciones jurisdiccionales" ${ }^{\text {" }}$.

\section{Concepto de "resolver sobre la totalidad de la sucesión"}

15. Los Gobiernos alemán y polaco y la Comisión señalan en sus observaciones que en la versión alemana del art. 4 del Reglamento (UE) 650/2012, se establece que serán competentes los tribunales del Estado miembro que tengan competencia respecto de "las resoluciones en sucesiones" (Für Entscheidungen in Erbsachen $)^{47}$. En consecuencia, se podría deducir que el art. 4 de la versión alemana de dicho instrumento internacional, exclusivamente determinaría la competencia en aquellos procedimientos en los que los órganos jurisdiccionales de los Estados miembros dictan "resoluciones" en el sentido del artículo 3.1.g) del Reglamento (UE) 650/2012 $2^{48}$

Sin embargo, el Abogado General Sr. M. Szpunar deja claro que en el artículo 4 de otras versiones lingüísticas del Reglamento sucesorio no figura el concepto de "resolución", sino que se hace referencia a "resolver" sobre la sucesión. Este es el caso de la versión inglesa (rule), la versión francesa (statuer) o la versión española, señalando esta última de forma literal: "tendrán competencia para resolver sobre la totalidad de la sucesión" "49. Por lo tanto, según el Abogado General, la dicción de la versión alemana del Reglamento no determina el alcance del concepto "resolver"s0.

16. En opinión del Abogado General, tampoco es algo obvio que las disposiciones que se refieren a "resolver" por parte de los órganos jurisdiccionales, estén refiriéndose a la forma verbal del concepto de "resolución" en el sentido que le otorga el art. 3.1.g), cuando en dicho art. 3 lo único que recoge son todas las definiciones del Reglamento sucesorio ${ }^{51}$.

La dificultad interpretativa es todavía mayor porque en la mayoría de las versiones lingüísticas del Reglamento (UE) 650/2012 se utilizó en el artículo 3.1.g), de forma redundante, el término "resolución"

\footnotetext{
${ }^{42}$ Ibidem, apartado 59.

${ }^{43}$ Idem, apartado 60.

${ }^{44}$ Idem, apartado 61.

${ }^{45}$ Idem, apartado 62.

${ }^{46}$ Idem, apartado 64.

${ }^{47}$ Idem, apartado 65.

${ }^{48}$ El art. 3 del Reglamento (UE) 650/2012 recoge las definiciones de dicho instrumento internacional.

${ }^{49}$ Según el Abogado General, un aspecto a favor de una interpetación amplia del art. 4 del Reglamento sucesorio sería el hecho de que este atribuye la competencia al Estado de la residencia habitual del causante en el momento del fallecimiento para resolver "sobre la totalidad de la sucesión" (Conclusiones del Abogado General Sr. M. Szpunar, presentadas el 22 de febrero de 2018, Vincent Pierre Oberle, C-20/17, ECLI:EU:C:2018:89, apartado 67).

${ }^{50}$ Conclusiones del Abogado General Sr. M. Szpunar, presentadas el 22 de febrero de 2018, Vincent Pierre Oberle, C-20/17, ECLI:EU:C:2018:89, apartado 66.

${ }^{51}$ Ibidem, apartado 68.
} 
para definir el concepto de "resolución" 52 . Esto sucede en la versión alemana, inglesa y francesa, mientras que en la versión polaca, sueca y española se utiliza otro término para la definición de resolución; que en el caso de la versión española se refiere a "decisión" para definir el concepto de "resolución".

17. Por último, el Abogado General Sr. M. Szpunar concluye que cuando el órgano jurisdiccional remitente, así como los Gobiernos alemán y francés, señalan la necesidad de interpretar el art. 4 del Reglamento (UE) 650/2012, en relación con la definición de "resolución" del art. 3.1.g), en el sentido de que "resolver" consiste en ejercer funciones jurisdiccionales, parece que hacen referencia al concepto de "resolución" que el Tribunal de Justicia ha elaborado en su jurisprudencia sobre las normas del "sistema de Bruselas" 53 .

\section{Concepto de "resolución"}

18. Efectivamente, en el "sistema de Bruselas" se define como resolución, "cualquier resolución (...) dictada por un tribunal de un Estado miembro", de forma que el TJUE ha aclarado que la "resolución" debe proceder de un órgano jurisdiccional que, en el ejercicio de su potestad jurisdiccional, resuelve sobre los puntos controvertidos entre las partes ${ }^{54}$.

El Considerando (59) del Reglamento (UE) 650/2012, en relación al reconocimiento de resoluciones, deja claro que es indiferente que la "resolución" se haya dictado en un procedimiento contencioso o no contencioso. Por lo tanto, no se puede exigir que la "resolución" en el sentido del art. 3.1.g) del Reglamento sucesorio tenga que referirse necesariamente a puntos controvertidos entre las partes, como sí que es obligatorio en el "sistema de Bruselas" 55 .

19. Por su parte, con el concepto de "resolver en el ejercicio de su potestad jurisdiccional", el TJUE normalmente se refiere a aquellas características de la actividad realizada por el órgano judicial, en la que desempeña una función decisiva y no se limita a desarrollar un papel más pasivo que consista, por ejemplo, en ratificar la voluntad de las partes del procedimiento ${ }^{56}$. De ahí que no sea considerado como resolución una transacción judicial "que reviste un carácter esencialmente contractual, puesto que su contenido depende, ante todo, de la voluntad de las partes". Sin embargo, no es sencillo determinar la actividad que debería realizar el órgano judicial para reconocer que éste ha dictado una "resolución" en el sentido del art. 3.1.g) del Reglamento (UE) 650/2012 $2^{57}$.

20. Por último, los fines del Reglamento (UE) 650/2012 y del "sistema de Bruselas" son diferentes. Las "resoluciones" en el sentido del art. 3.1.g) del Reglamento sucesorio pueden ser también dictadas por autoridades no judiciales siempre que cumplan con los requisitos establecidos en el art. 3.2 del mismo instrumento internacional. Estos requisitos pretenden garantizar que las resoluciones de estas autoridades "tengan fuerza y efectos análogos a los de la resolución de un órgano judicial sobre la misma materia" objeto del Reglamento sucesorio (art. 3.2.b) Reglamento (UE) 650/2012).

Sin embargo, el fin de las normas del "sistema de Bruselas" es garantizar el traslado libre de las resoluciones en materia civil y mercantil; mientras que constituye un fin primordial para el Reglamento

\footnotetext{
${ }^{52}$ Idem, apartado 69.

${ }^{53}$ Idem, apartado 70.

${ }^{54}$ Idem, apartado 71.

${ }^{55}$ Idem, apartado 73.

${ }^{56}$ Vid. Conclusiones del Abogado General Sr. Y. Bot, presentadas el 6 de septiembre de 2012, Gothaer Allgemeine Versicherung y otros c. Samskip GmbH, C-456/11, EU:C:2012:554, apartado 38. En esta misma línea interpretativa, vid. X. KRAMER, en U. Magnus/P. Mankowski (eds.), Brussels I bis Regulation, Verlag Otto Schmidt, Colonia, 2016, p. 987. Esta postura también se adopta en relación con el Reglamento (UE) 650/2012. En este sentido vid., P. WaUtelet, "Article 3: Definitions", en A. Bonomi/P. Wautelet/I. Pretelli/A. Öztürk, Le droit européen des successions. Commentaire du Règlement $n^{o}$ 650/2012 du 4 juillet 2012, 2a ed., Bruylant, Bruxelles, 2016, p. 162.

${ }^{57}$ Conclusiones del Abogado General Sr. M. Szpunar, presentadas el 22 de febrero de 2018, Vincent Pierre Oberle, C-20/17, ECLI:EU:C:2018:89, apartado 74.
} 
sucesorio la supresión de dificultades a la hora de ejercer sus derechos en situaciones de sucesión mortis causa con repercusiones transfronterizas ${ }^{58}$.

Por lo tanto, según el Abogado General, el umbral de los requisitos que se le tienen que exigir a la "resolución" no tiene que ser igual de elevado que en el caso de las normas del sistema de Bruselas, sobre todo, en el contexto de la actividad relacionada con la expedición de la resolución. Es más, ello no quiere decir que "resolver" en el sentido del art. 4 del Reglamento (UE) 650/2012 implique tener que expedir una "resolución", cuyo concepto ha sido elaborado por el TJUE para el "sistema de Bruselas" 59 .

21. Según el Abogado General Sr. M. Szpunar, todo lo anterior puede ser un indicio de que las normas de competencia no solo deberían ser aplicables en aquellos procedimientos en que los órganos jurisdiccionales dictan "resoluciones" en el sentido del art. 3.1.g) del Reglamento (UE) 650/2012 ${ }^{60}$.

A la vista de las observaciones, el Sr. M. Szpunar considera que las conclusiones que dimanan de la interpretación literal del art. 4 del Reglamento (UE) 650/2012 no son unívocas y, por ello, deberían confrontarse con la interpretación sistemática de este Reglamento ${ }^{61}$.

Aunque efectivamene puede ser discutible que en el caso planteado el órgano judicial esté ejerciendo funciones jurisdiccionales, si se hubiera tratado de "las demás autoridades y profesionales del Derecho" la solución hubiese sido diferente, porque para que puedan ser consideradas "tribunales" es necesario que cumplan obligatoriamente funciones jurisdiccionales. Así sucedió en el asunto WB c. Notariusz Przemystawa $B a c$ que ha sido mencionado, en el que tras un análisis del concepto "funciones jurisdiccionales" y de su aplicación al caso concreto, se determinó que los notarios polacos, que tenían que redactar un documento a solicitud de todas las partes del procedimiento notarial, no ejercían funciones jurisdiccionales ${ }^{62}$.

En definitiva, para el TJUE es más difícil dictaminar que cuando son los órganos judiciales los que emiten los certificados sucesorios nacionales, no están ejerciendo "funciones jurisdiccionales"; así que para que decidan que no las ejercen, las circunstancias del caso deben ser determinantes y que no existan dudas al respecto; mientras que sí las había en el asunto Vincent Pierre Oberle. Además, el TJUE será más proclive a que, en el caso de planaterse asuntos similares, en los que quien expide el certificado sucesorio nacional es un órgano judicial, éste tenga que respetar obligatoriamente las normas de competencia del Reglamento (UE) 650/2012. Me estoy refiriendo a que, por cuestiones de economía procesal, si es un órgano judicial el que realiza el certificado sucesorio nacional, dicho órgano judicial estará obligado a cumplir las normas de competencia internacional, sin tener que entrar a analizar los aspectos del caso concreto. Este, efectivamente, ha sido el fallo de la sentencia del Vincent Pierre Oberle, después de que el TJUE haya tenido en cuenta las distintas interpretaciones relizadas por el Abogado General, que se detallan más adelante.

Mientras que, por otro lado, si se trata de autoridades no judiciales, que desempeñan distintas funciones en un mismo Estado miembro y a su vez entre Estados miembros, el TJUE considera que se debe analizar si la autoridad no judicial cumple funciones jurisdiccionales en un Estado miembro, para el asunto en cuestión. Un ejemplo de esto es la sentencia del TJUE en el asunto WB c. Notariusz Przemystawa $B a c^{63}$. Lo cual es lógico, porque las autoridades no judiciales, no siempre cumplen funciones jurisdiccionales en el sentido del Reglamento (UE) 650/2012.

\section{El art. 4 del Reglamento (UE) 650/2012 en el contexto de otras normas del capítulo II de dicho Reglamento}

22. El Abogado General en sus Conclusiones relativas al asunto Vincent Pierre Oberle realiza una interpretación sistemática como consecuencia de las conclusiones poco claras que derivan de la in-

\footnotetext{
${ }^{58}$ Considerando (7) Reglamento (UE) 650/2012 (Conclusiones del Abogado General Sr. M. Szpunar, presentadas el 22 de febrero de 2018, Vincent Pierre Oberle, C-20/17, ECLI:EU:C:2018:89, apartado 76).

${ }^{59}$ Ibidem, apartado 75.

${ }^{60}$ Idem, apartado 76.

${ }^{61}$ Idem, apartado 77.

${ }^{62}$ Conclusiones del Abogado General Sr. Y. Bot, presentadas el 28 de febrero de 2019, WB c. Notariusz Przemysława Bac, C-658/17, ECLI:EU:C:2019:166, apartados 81-98.

${ }^{63}$ STJUE 23 mayo 2019, WB c Notariusz Przemystawa Bac, C-658/17, ECLI:EU:C:2019:444, apartado 73.
} 
terpretación literal del art. 4 del Reglamento (UE) 650/2012. Para el análisis del art. 4 en el contexto de otras disposiciones de este Reglamento, se tendrán únicamente en cuenta las disposiciones incluidas en su capítulo II, puesto que son las normas que regulan la competencia con respecto de los procedimientos de sucesiones ${ }^{64}$.

En definitiva, el Sr. M. Szpunar pretende determinar si las otras normas de competencia incluidas en el capítulo II determinan la competencia con respecto a aquellos procedimientos en los que no se llega a dictar una "resolución" en el sentido del art. 3.1.g) del Reglamento (UE) 650/2012.

23. Concretamente el art. 13 del Reglamento sucesorio atribuye la competencia para recibir declaraciones hereditarias, tales como declaraciones sobre aceptación de la herencia, de un legado o de la parte legítima o la renuncia a los mismos, o una declaración de limitación de su responsabilidad respecto a las deudas y demás cargas de la herencia. Pues bien, esta disposición prevé que "además del tribunal que sea competente para pronunciarse sobre la sucesión en virtud del (...) Reglamento", son competentes para conocer de tales declaraciones los tribunales del Estado miembro de la residencia habitual de la persona facultada para efectuar tal declaración ${ }^{65}$.

Según el Abogado General, la expresión "además del tribunal que sea competente para pronunciarse sobre la sucesión en virtud del presente Reglamento" puede significar que las normas de competencia del capítulo II del Reglamento (UE) 650/2012, incluido el art. 4, atribuyen también la competencia para conocer de declaraciones hereditarias, aunque ello no se produzca en el marco de procedimientos en los que se llega a dictar una "resolución" en el sentido del art. 3.1.g) de este Reglamento ${ }^{66}$. Por lo tanto, no debe entenderse únicamente por "pronunciarse" o "resolver", el dictar "resoluciones" con base en dicho precepto.

24. Se llega a conclusiones similares, mediante el análisis del art. 13 del Reglamento (UE) $650 / 2012$, en el que se usa la preposición "además del" en el contexto de su entorno normativo. El capítulo II comienza con la disposición que atribuye la competencia general para "resolver sobre la totalidad de la sucesión" (art. 4 Reglamento (UE) 650/2012). A continuación, las disposiciones siguientes de este capítulo señalan la competencia de los tribunales de otros Estados miembros, siempre que concurran los requisitos establecidos en dichos preceptos (arts. 5, 7, 9, 10 y 11 Reglamento (UE) 650/2012) ${ }^{67}$.

Por lo tanto, el art. 13 del Reglamento se insertó al final de una enumeración correlativa de los tribunales que son competentes para resolver sobre la totalidad de las cuestiones relativas a la suce$\operatorname{sión}^{68}$. En la medida en que "resolver sobre la totalidad de la sucesión" también implique conocer de las declaraciones hereditarias, "además" de estos tribunales, también serán competentes los órganos jurisdiccionales del Estado miembro de la residencia habitual de la persona facultada para efectuar tal declaración ${ }^{69}$.

25. Tras estas consideraciones, el Abogado General concluye que a la luz de la interpretación sistemática de las normas del capítulo II del Reglamento (UE) 650/2012, el art. 4 atribuye la competencia respecto de los procedimientos planteados ante los órganos jurisdiccionales de los Estados miembros cuando estos procedimientos se refieren a materias que pueden considerarse que entran dentro de "la totalidad de la sucesión", con independencia de que este procedimiento sea o no contencioso ${ }^{70}$.

${ }^{64}$ Idem, apartado 78.

${ }^{65}$ Idem, apartado 79.

${ }^{66}$ Aboga por esta interpretación el Considerando (32) del Reglamento (UE) 650/2012, del que se desprende que se ha adoptado el art. 13 con el fin de "facilitar la vida a los herederos y legatarios" y con el fin de atribuir la competencia respecto de una materia a la que no se refieren las otras normas de competencia del Reglamento (Conclusiones del Abogado General Sr. M. Szpunar, presentadas el 22 de febrero de 2018, Vincent Pierre Oberle, C-20/17, ECLI:EU:C:2018:89, apartados 80 y 81).

${ }^{67}$ Conclusiones del Abogado General Sr. M. Szpunar, presentadas el 22 de febrero de 2018, Vincent Pierre Oberle, C-20/17, ECLI:EU:C:2018:89, apartado 82.

${ }^{68}$ Ibidem, apartado 83.

${ }^{69}$ Siguiendo con esta misma idea vid. Conclusiones del Abogado General Sr. M. Szpunar, presentadas el 22 de febrero de 2018, Vincent Pierre Oberle, C-20/17, ECLI:EU:C:2018:89, apartado 84.

${ }^{70}$ Conclusiones del Abogado General Sr. M. Szpunar, presentadas el 22 de febrero de 2018, Vincent Pierre Oberle, C-20/17, 
Por lo tanto, habrá que determinar si la expedición de los certificados sucesorios nacionales se encuentra dentro del concepto "la totalidad de la sucesión", siendo de aplicación las normas de competencia del art. 4 del Reglamento sucesorio a la expedición de los mismos. Sobre este aspecto inciden el órgano jurisdiccional remitente, así como los Gobiernos alemán y francés, que afirman que al haber incluido el art. 64, que regula la competencia para la expedición de los certificados sucesorios europeos, se puede concluir que el art. 4 no atribuye la competencia respecto de los procedimientos de expedición de certificados sucesorios nacionales, al considerar que están excluidos ${ }^{71}$.

Pero para poder entender la interpretación sistemática que realiza el Abogado General, al poner en relación el art. 4 con el art. 64 del Reglamento sucesorio, es necesario explicar previamente el art. 64 que señala la competencia internacional para la expedición de los certificados sucesorios europeos.

\section{Competencia internacional en materia de expedición de certificados sucesorios europeos}

26. La competencia internacional para la expedición de los certificados sucesorios europeos está contenida en el art. 64 del Reglamento (UE) 650/2012, que señala de forma literal: "El certificado será expedido en el Estado miembro cuyos tribunales sean competentes en virtud de los artículos 4, 7, 10 u 11. La autoridad expedidora deberá ser: a) un tribunal tal como se define en el artículo 3, apartado 2, u b) otra autoridad que, en virtud del Derecho nacional, sea competente para sustanciar sucesiones mortis causa".

Sin embargo, este precepto ha sido objeto de un intenso debate por parte de la doctrina a raíz de que se dio a conocer la Proposición del Reglamento sucesorio por parte de la Comisión; y que sigue estando latente en la actualidad, como se podrá comprobar a continuación ${ }^{72}$.

\section{El art. 64 del Reglamento (UE) 650/2012}

27. La redacción del art. 64 del Reglamento sucesorio es poco clara al respecto y el texto legal no ha querido pronunciarse al respecto y fijar, de modo expreso, cuál es la autoridad competente para expedir el certificado sucesorio europeo ${ }^{73}$. En consecuencia, tal y como señala J. CARRASCOSA GonZÁLEZ, se pueden realizar dos interpretaciones del mismo $^{74}$ :

a) Tesis de la competencia única. Según la cual serían competentes las autoridades del Estado miembro que sean internacionalmente competentes para sustanciar una sucesión mortis causa en virtud del Reglamento (UE) 650/2012. En cuyo caso, los foros de competencia recogidos en el Reglamento (UE) 650/2012 operarían, a efectos de expedir el certificado sucesorio europeo, como foros estructurados en cascada. Esta tesis tiene su apoyo en el Considerando (70) que establece: "El certificado se debe expedir en el Estado miembro cuyos tribunales sean competentes en virtud del presente Reglamento".

b) Tesis de la competencia alternativa. Según esta tesis, el art. 64 no indica que son competentes, exclusivamente, las autoridades del Estado miembro que sean competentes para sustanciar una

ECLI:EU:C:2018:89, apartado 85. Vid. L. Perreau-SAussine, "Quelle place pour les certificats successoraux nationaux dans le règlement européen Successions internationales, nº 650/2012?”, Revue Critique Droit International Privé, octobre-décembre 2018, pp. 853-854.

${ }^{71}$ Conclusiones del Abogado General Sr. M. Szpunar, presentadas el 22 de febrero de 2018, Vincent Pierre Oberle, C-20/17, ECLI:EU:C:2018:89, apartado 77.

72 Vid. R. Crône, "Le certificat succesoral européen”, en G. Khatrallah/M. Revillard, Perspectives du droit des successions européenes et internationales, Étude de la proposition de Règlement du 14 octobre 2009, Defrénois, Paris, 2010, pp. 163-165; P. Wautelet, “Article 3: Definitions” en A. Bonomi/P. Wautelet/I. Pretelli/A. Öztürk, Le droit européen des successions. Commentaire du Règlement $n^{o}$ 650/2012 du 4 juillet 2012, 2a ed., Bruylant, Bruxelles, 2016, p. 171.

${ }^{73}$ P. Chassaing, "La préparation des notaires et du notariat concernnant la mise en application du réglement du 4 juillet 2012", en AA.VV. (sous la direction de G. Khairallah/M. Revillard), Droit européen des successions internationales (Le Règlement du 4 juillet 2012), Defrénois, Paris, 2013, pp. 40-42.

${ }^{74}$ J. Carrascosa GonzÁlez, "Reglamento sucesorio europeo y actividad notarial", Cuadernos de Derecho Transnacional, vol. $6, \mathrm{n}^{\circ} 1$, marzo 2014, p. 41. 
sucesión mortis causa en virtud del Reglamento (UE) 650/2012. Lo que expresa el art. 64 es que cualquiera de los Estados miembros designados por los arts. 4, 7, $10 \mathrm{u} 11$ es competente para expedir un certificado europeo (art. 64 in primis Reglamento (UE) 650/2012: "El certificado será expedido en el Estado miembro cuyos tribunales sean competentes en virtud de los artículos 4, 7, 10 u 11"). Por lo tanto, existiría una "competencia internacional concurrente" para la expedición del certificado sucesorio europeo, por lo que un particular podrá dirigirse a las autoridades de cualquiera de los Estados miembros a los que conducen los preceptos citados.

28. Por lo tanto, en el caso de que los notarios de un Estado miembro fuesen designados como autoridad competente para expedir el certificado sucesorio europeo, en opinión de J. CARRASCOSA GoNZÁLEZ parece que el art. 64 sólo otorga competencia internacional al efecto a los notarios del Estado miembro cuyos tribunales sean competentes en virtud de los arts. 4 (foro de la residencia habitual del causante), 7 (foro de la nacionalidad del causante), 10 (foro del lugar de situación de los bienes) u 11 (foro de necesidad) ${ }^{75}$.

Sin embargo, según la interpretación realizada por R. CRÔNE, en relación a los notarios franceses, como operan de modo extrajudicial, éstos pueden hacer valer su "competencia universal" 76 . Esta interpretación conduce a afirmar que los notarios pueden expedir el certificado sucesorio europeo si el Derecho nacional del Estado miembro al que pertenecen les otorga competencia internacional al efecto, sin que sea preciso que concurran los foros de competencia internacional recogidos en el Reglamento 650/2012 $2^{77}$. Esta tesis se apoya tanto en el art. 2, que señala: "el presente Reglamento no afectará a las competencias de las autoridades de los Estados miembros en materia de sucesiones"; como en el Considerando (29): "cuando el tribunal no haya incoado de oficio el procedimiento sucesorio, el presente Reglamento no debe obstar para que las partes resuelvan extrajudicialmente la sucesión, por ejemplo ante un notario, en un Estado miembro que hayan elegido, en caso de que ello sea posible en virtud de la ley de dicho Estado miembro (...)"; y en el Considerando (36): "dado que las sucesiones en algunos Estados miembros pueden ser sustanciadas por autoridades no judiciales, como los notarios, que no están vinculadas por las normas de competencia establecidas en el presente Reglamento (...)”. En opinión de J. CARRASCOSA GonzÁlez, la victoria notarial es clara, puesto que mientras los tribunales están "limitados" por los foros recogidos en el Reglamento para expedir el certificado sucesorio europeo, los notarios no lo están, por lo que podrán expedir el certificado sucesorio europeo en un mayor número de casos que los tribunales, lo cual no deja de resultar paradójico ${ }^{78}$.

En este mismo sentido P. WAUTELET señala que, aunque los notarios no sean calificados como "tribunales", nada impide que sean considerados una autoridad que pueda emitir un certificado sucesorio europeo, puesto que según el art. 64, este puede ser emitido no sólo por un "tribunal" sino por "otra autoridad que, en virtud del Derecho nacional, sea competente para sustanciar sucesiones mortis causa". En consecuencia, los notarios pueden ser llamados a intervenir en el marco de la sucesión para realizar diversos actos como son la redacción del testamento, por lo que no sería considerado un tribunal. Sin embargo, los notarios también pueden ser instados para la expedición de un certificado sucesorio euro-

75 J. Carrascosa GonzÁlez, "Reglamento sucesorio europeo y actividad notarial”, Cuadernos de Derecho Transnacional, vol. 6, $\mathrm{n}^{\circ}$ 1, marzo 2014, p. 42. En esta misma línea interpretativa vid., P. LAGARDE, "Les principes de base du nouveau règlement européen sur les successions", Revue Critique Droit International Privé, octobre-décembre 2012, p. 729; A. Bonomi, "Il regolamento europeo sulle successioni“, Rivista di diritto internazionale e processuale, 2013, p. 321; A. DAvì/A. ZANOBETTI, "Il nuovo diritto internazionale privato delle successioni nell'Unione Europea”, Cuadernos de Derecho Transnacional, (Octubre 2013), Vol. 5, No 2, p. 134; D. Stamatiadis, "Chapter VI: European Certificate of Succession”, en H. Pamboukis (ed.), EU Succession Regulation N N . 650/2012: A Commentary, C.H. Beck/Hart Publishing, Oxford, 2017, pp. 599-603; I. AnTón JuÁrez, "Certificado Sucesorio Europeo", en A.-L. Calvo Caravaca/J. CARrascosa González (dirs.), Litigación Internacional en la Unión Europea (IV): Comentario al Reglamento (UE) núm. 650/2012 del Parlamento Europeo y del Consejo sobre sucesiones mortis causa, Aranzadi, Navarra, 2019, p. 336.

${ }^{76}$ R. CRÔNE, "Le certificat succesoral européen", en AA.VV. (sous la direction de G. KhaIRALlah/M. ReVILlard), Droit européen des successions internationales (Le Règlement du 4 juillet 2012), Defrénois, Paris, 2013, pp. 178-179.

77 J. CARrascosa GonzÁlez, "Reglamento sucesorio europeo y actividad notarial", Cuadernos de Derecho Transnacional, vol. 6 , nº 1 , marzo 2014 , p. 42.

78 J. CARrascosa GonzÁlez, "Reglamento sucesorio europeo y actividad notarial", Cuadernos de Derecho Transnacional, vol. $6, \mathrm{n}^{\circ} 1$, marzo 2014 , p. 42. 
peo, lo cual será bastante frecuente, cuando el Estado miembro haya indicado que el notario constituye "otra autoridad" en el sentido del art. 64.b) del Reglamento. Así que sólo en casos excepcionales los notarios podrían ser considerados como "tribunales" y por tanto, estar vinculados por las normas de competencia del Reglamento ${ }^{79}$.

29. Los Estados miembros notificarán a la Comisión, las autoridades y los profesionales del Derecho que se consideran "tribunales" tal y como se definen en el art. 3.2 del Reglamento (UE) 650/2012 (art. 3.2. último párrafo), de conformidad con el art. 79.1 ${ }^{80}$. Por lo tanto, los Estados miembros deben notificar una "lista" de "tribunales", a los efectos del Reglamento. Si se modificara esa lista, los Estados miembros lo deben notificar a la Comisión para que pueda modificarla en consecuencia. La Comisión se encarga de publicar la lista y toda modificación ulterior en el Diario Oficial de la Unión Europea, y además hará pública toda la información notificada por los Estados miembros respecto a la lista de tribunales, por cualquier medio adecuado, en particular a través de la Red Judicial Europea en materia civil y mercantil (arts. 79.2, 3 y 4 Reglamento (UE) núm. 650/2012). Esta lista ya está publicada en la "Información sobre los Estados miembros y formularios en línea relativos al Reglamento n. ${ }^{\circ}$ 650/2012" " .

Así pues, Francia ha señalado que los notarios no ejercen funciones jurisdiccionales, y que no son un "tribunal" en el sentido del Reglamento ${ }^{82}$. Por lo tanto, no ha hecho ninguna comunicación al respecto, de conformidad con el art. 79.1 del Reglamento (UE) 650/2012, indicando que los notarios deben ser considerados "tribunales" en el sentido del art. 3.2 del Reglamento (UE) 650/2012. Sin embargo, Francia ha señalado, en relación con las autoridades competentes para emitir el certificado sucesorio europeo (art. 78.1.c) Reglamento (UE) 650/2012), que "El certificado sucesorio europeo (ECS) será expedido por un notario (artículo 1381-1 de la Ley de enjuiciamiento civil)"»3.

${ }^{79}$ P. Wautelet, “Article 3: Definitions” en A. Bonomi/P. Wautelet/I. Pretelli/A. Öztürk, Le droit européen des successions. Commentaire du Règlement $n^{\circ}$ 650/2012 du 4 juillet 2012, 2a ed., Bruylant, Bruxelles, 2016, pp. 178-179. Aunque parte de la doctrina no esté de acuerdo, en opinión del legislador alemán, es el derecho nacional el que regula la competencia internacional para la expedición del certificado sucesorio europeo, independientemente de los art. 4 y siguientes del Reglamento, relativos a la competencia judicial internacional (E. GeIMER, "Die Ermittlung des gewöhnlichen Aufenthaltes des Erblassers durch das Nachlassgericht”, en R.A. Schüтze (HrsG.), Fairness Justice Equity: Festschrift für Reinhold Geimer zum 80. Geburtstag, München, Beck, 2017, pp. 117-118). También GaudEmET-TALLon ha señalado que en Francia los notarios no ejercen funciones jurisdiccionales, pues considera que no son un "tribunal" en el sentido del Reglamento, por lo que su competencia deriva del derecho nacional francés (H. GAUDEMET-TALLON, "LES RĖGLES DE COMPÈTENCE JUDICIARIE DANS LE RĖGLEMENT EUROPÉEN SUR LES successions", en AA.VV. (sous la direction de G. Khairallah/M. Revillard), Droit européen des successions internationales (Le Règlement du 4 juillet 2012), Defrénois, Paris, 2013, p. 129).

${ }^{80}$ En cuanto a la notificación o comunicación que deberán hacer los Estados miembros en el asunto WB c Notariusz Przemystawa Bac se señala al respecto que la falta de notificación a que se refiere el artículo 3.2 en su párrafo segundo, del Reglamento (UE) 650/2012, por parte de la República de Polonia, relativa al ejercicio por los notarios de funciones jurisdiccionales, no tiene carácter definitivo. Esto quiere decir que si los Estados no notifican que sus notarios son "otras autoridades" en el sentido del art. 3.2 Reglamento sucesorio, no implica que no puedan ser considerados "tribunal" y estar sometidos a las normas de competencia internacional del mismo. El Abogado General Sr. Y. Bot señala que dicha calificación debe ser realizada por el órgano jurisdiccional nacional en cuestión, de forma autónoma, de manera que en cualquier caso la declaración realizada por la autoridad nacional competente no vincula a dicho órgano jurisdiccional; y eso se extrapolaría a los casos de ausencia de declaración. Vid. STJUE 23 mayo 2019, WB c Notariusz Przemysława Bac, C-658/17, ECLI:EU:C:2019:444, apartados 4049; Conclusiones del Abogado General Sr. Y. Bot, presentadas el 28 de febrero de 2019, WB c. Notariusz Przemystawa Bac, C-658/17, ECLI:EU:C:2019:166, apartados 64-69.

${ }^{81}$ La página en la que aparecen las comunicaciones de los Estados miembros es https://e-justice.europa.eu/content_succession-380-es.do?clang=es (E. Castellanos Ruiz, "Sucesión Hereditaria. El Reglamento Sucesorio Europeo", en A.-L. Calvo Caravaca/J. Carrascosa González (dirs.), Derecho Internacional Privado, Volumen II, Comares, Granada, 2018, p. 599).

${ }^{82}$ H. Gaudemet-Tallon, "Les Règles de Compètence judiciarie dans le règlement européen sur les Successions", eN AA.VV. (sous la direction de G. Khairallah/M. ReVIllard), Droit européen des successions internationales (Le Règlement du 4 juillet 2012), Defrénois, Paris, 2013, p. 129; L. Perreau-Saussine, "Quelle place pour les certificats successoraux nationaux dans le règlement européen Successions internationales, $n^{\circ}$ 650/2012?", Revue Critique Droit International Privé, octobredécembre 2018, p. 858.

${ }^{83}$ La comunicación con respecto a las autoridades que son competentes para emitir el certificado sucesorio europeo, así como otras notificaciones previstas en el Reglamento (UE) 650/2012, de conformidad con los arts. 78 y 79 , que Francia ha realizado, están disponibles en línea en https://e-justice.europa.eu/content succession-380-fr-es.do?member=1 (consultada el 10 de diciembre de 2019). 
En esta misma línea, ni Alemania, ni Bélgica han realizado ninguna notificación de conformidad con el art. 79.1 del Reglamento (UE) 650/2012, indicando que los notarios deben ser considerados "tribunales" a efectos del art. 3.2 del Reglamento (UE) 650/2012 $2^{84}$. Sin embargo, de acuerdo con el art. 78.1.c), ambos países sí que han notificado a la Comisión que los notarios son "otra autoridad" a efectos de la expedición del certificado en virtud del artículo 64 del Reglamento (UE) 650/2012. Por ejemplo, Bélgica ha señalado de forma literal que "Las autoridades competentes a efectos de la expedición del certificado en virtud del artículo 64 son los notarios"

En consecuencia, a diferencia de España, ninguno de los Estados miembros mencionados ha señalado que los notarios deban ser considerados "tribunal" en el sentido del art. 3.2 del Reglamento sucesorio, por lo tanto, no están sujetos a las normas de competencia judicial internacional, como es el caso del art. 4 de dicho instrumento internacional. Es más no han hecho niguna notificación con respecto a qué otras autoridades o profesionales del Derecho deben ser considerados "tribunal", además de los órganos judiciales; así que en dichos Estados miembros únicamente los órganos judiciales están sujetos a las normas de competencia judicial internacional del capítulo II del Reglamento sucesorio.

Sin embargo, dichos Estados miembros sí que han comunicado a la Comisión quiénes son "otra autoridad" para emitir los certificados sucesorios europeos, además de los órganos judiciales. Han señalado concretamente que los notarios que, en virtud su Derecho nacional, son competentes para sustanciar sucesiones mortis causa, son competenes para la expedición de los certificados sucesorios europeos. Por lo tanto, si se sigue la línea interpretativa de R. CRÔNE y P. WAUTELET, los notarios no tienen que respetar las normas de competencia internacional, sino que su competencia deriva del derecho nacional del Estado miembro en cuestión.

30. Comunicaciones de España a la Comisión, de conformidad con los arts. 78.1.c) y 79.1. En el caso de España la situación en relación con los notarios es diferente porque España ha hecho las dos declaraciones, de conformidad con los arts. 78.1.c) y 79.1 del Reglamento (UE) 650/2012.

Así España ha comunicado a la Comisión, conforme establece el art. 79.1 del Reglamento (UE) 650/2012, que los "notarios" son "otras autoridades" en el sentido del art. 3.2 del Reglamento (UE) $650 / 2012$ y que, por tanto, ejercen "funciones jurisdiccionales" 86 . España ha señalado que, en relación a determinados actos de jurisdicción voluntaria, los notarios ejercen funciones jurisdiccionales, concretamente ha notificado que son considerados "tribunal" "17: "los notarios, en relación a las declaraciones de herederos abintestato, a los procedimientos de presentación, adveración, apertura y protocolización de los testamentos cerrados, ológrafos y orales y a la formación de inventario" ${ }^{88}$. Y a continuación indica

${ }^{84}$ La comunicación indicando que los notarios deben ser considerados "tribunal" en el sentido del art. 3.2 del Reglamento (UE) 650/2012; o la notificación señalando si los notarios son "otra autoridad" en el sentido del art. 64 del Reglamento sucesorio, y que por tanto, son competentes para emitir el certificado sucesorio europeo, además de los tribunales; así como otras notificaciones previstas en el Reglamento (UE) 650/2012, de conformidad con los arts. 78 y 79; están disponibles en línea para Alemania en https://e-justice.europa.eu/content_succession-380-de-es.do?member=1; y para Bélgica en https://e-justice.europa.eu/content_succession-380-be-es.do?member=1 (consultadas el 10 de diciembre de 2019).

${ }^{85}$ Las notificaciones de Bélgica, de conformidad con los arts. 78 y 79 del Reglamento (UE) 650/2012, están disponibles en línea en https://e-justice.europa.eu/content_succession-380-be-es.do?member=1 (consultada el 10 de diciembre de 2019).

${ }^{86}$ E. Castellanos Ruiz, "Sucesión Hereditaria. El Reglamento Sucesorio Europeo", en A.-L. Calvo Caravaca/J. CarrasCOSA GonzÁlez (dirs.), Derecho Internacional Privado, Volumen II, Comares, Granada, 2018, p. 686. Hasta que España no hizo la comunicación de las tareas específicas en las que los notarios desarrollaban funciones jurisdiccionales, en virtud del art. 79.1, no estaba claro si los notarios tenían que respetar las normas de competencia judicial internacional en relación con determinados actos de jurisdicción voluntaria, como la declaración de herederos abintestato, por ser considerada una "actividad jurisdiccional". Para un mayor análisis de la competencia internacional notarial y el Reglamento (UE) 650/2012 vid. J. CARRASCOSA GonzÁlez, "Aspectos prácticos de la función notarial en el Reglamento Sucesorio Europeo", en M. EsPeranÇA GinEBRA Molins/J. Tarabal Bosch (dirs.), El Reglamento (UE) 650/2012: su impacto en las sucesiones trasnfronterizas, Marcial Pons, Madrid, 2016, pp. 339-348.

${ }^{87}$ Para un mayor desarrollo de los tipos de actos (de jurisdicción voluntaria y otros) que realizan los notarios vid. J. CARRASCOSA GonzÁlez, “Aspectos prácticos de la función notarial en el Reglamento Sucesorio Europeo”, en M. EsPeranÇA GINEBRA Molins/J. Tarabal Bosch (dirs.), El Reglamento (UE) 650/2012: su impacto en las sucesiones trasnfronterizas, Marcial Pons, Madrid, 2016, pp. 345-347.

${ }^{88}$ Las notificaciones de España, de conformidad con los arts. 78 y 79 del Reglamento (UE) 650/2012, están disponibles en línea en https://e-justice.europa.eu/content_succession-380-es-es.do?member=1 (consultada el 10 de diciembre de 2019). 
los notarios territorialmente competentes en España para realizar estos actos de jurisdicción voluntaria: "Arts. 55 y 56; 57 a 65 y 67 a 68 de la Ley del Notariado, en redacción dada por la Disposición Final $11^{a}$ de la Ley 15/2015, de 2 de julio, de la Jurisdicción Voluntaria" "89.

En consecuencia, para estos actos de jurisdicción voluntaria, entre los que no se han incluído las actuaciones relativas a los contadores partidores o la aprobación de la partición-que también son actos de jurisdicción voluntaria- los notarios están sometidos a las normas de competencia judicial internacional ${ }^{90}$. De manera que, si no se cumple ningún foro de competencia internacional de los señalados en el capítulo II del Reglamento (UE) 650/2012 que atribuya competencia a un "tribunal", ningún notario español podrá realizar ninguno de los actos de jurisdicción voluntaria antes indicados. Una vez que exista un foro de competencia internacional, será territorialmente competente el notario establecido por la Ley del Notariado, en virtud de los preceptos arriba señalados.

31. Ahora bien, el problema se plantea porque en relación con los certificados sucesorios europeos, España ha comunicado a la Comisión de forma literal que dicho certificado "Se expedirá por órgano judicial o notario competente en cada caso", de conformidad con los arts. 78.1.c) del Reglamento (UE) $650 / 2012^{91}$. Dado que España ya había realizado la anterior comunicación señalando que los notarios deben ser considerados "tribunales", en el sentido del art. 3.2 del Reglamento (UE) 650/2012, para los actos de jurisdicción voluntaria indicados; los notarios ya eran autoridad competente para expedir los certificados sucesorios europeos que derivan de dichos expedientes. Efectivamente el art. 64 del Reglamento (UE) 650/2012 señala que son autoridad competente para emitirlos tanto "los tribunales" según se define en el art. 3.2; como "otra autoridad" que, en virtud del Derecho nacional, sea competentes para sustanciar sucesiones mortis causa. Por lo que, además, con esta segunda notificación, los notarios españoles son "otra autoridad" para expedir certificados sucesorios europeos derivados de otros actos.

Así que cuando se trate de realizar un certificado sucesorio europeo que derive de un expediente de jurisdicción voluntaria relativo a cualquiera de los actos notificados a la Comisión, de conformidad con el art. 79.1, y por tanto ser considerado "tribunal", el notario español no podrá declararse competente -en virtud de la Ley del Notariado-, si no cumple previamente con algún foro de competencia internacional del Reglamento (UE) 650/2012. Pero en relación con el resto de actos no notificados a la Comisión, como son las actuaciones relativas a los contadores partidores o la aprobación de la partición, el notario español no tendrá que respetar las normas de competencia internacional del Reglamento (UE) 650/2012; y podrá hacerlo para dichos actos en virtud del art. 66 de la Ley del Notariado ${ }^{92}$. En la comunicación de España a la Comisión no se incluyeron las actuaciones sobre albaceas o contadores, ni tampoco la aprobación de la partición, porque sólo notificó los expedientes sucesorios en los que los notarios poseen competencia exclusiva que sean actos de jurisdicción voluntaria ${ }^{93}$. Efectivamente, dichas actividades en los supuestos de los arts. 843 y $1057 \mathrm{CC}$ se realizan de forma alternativa con los Secretarios judiciales (Letrados de la Administración de Justicia) ${ }^{94}$. Ahora bien, si las actuaciones sobre los albaceas o conta-

\footnotetext{
${ }^{89}$ Las notificaciones de España, de conformidad con los arts. 78 y 79 del Reglamento (UE) 650/2012, están disponibles en línea en https://e-justice.europa.eu/content_succession-380-es-es.do?member=1 (consultada el 10 de diciembre de 2019).

${ }^{90}$ En este sentido vid. J. Carrascosa GonzÁlez, "Aspectos prácticos de la función notarial en el Reglamento Sucesorio Europeo", en M. Esperança Ginebra Molins/J. Tarabal Bosch (dirs.), El Reglamento (UE) 650/2012: su impacto en las sucesiones trasnfronterizas, Marcial Pons, Madrid, 2016, pp. 339-348.

${ }^{91}$ Las notificaciones de España, de conformidad con los arts. 78 y 79 del Reglamento (UE) 650/2012, están disponibles en línea en https://e-justice.europa.eu/content_succession-380-es-es.do?member=1 (consultada el 10 de diciembre de 2019).

92 Art. 66 Ley del Notariado de 1862, Gaceta de Madrid núm. 149, de 29 mayo 1862, modificado por la Disposición Final undécima de la Ley 15/2015 de la Jurisdicción Voluntaria (BOE núm. 158, de 3 julio 2015: "Será competente el Notario que tenga su residencia en el lugar en que hubiera tenido el causante su último domicilio o residencia habitual, o donde estuviere la mayor parte de su patrimonio, con independencia de su naturaleza de conformidad con la ley aplicable, o en el lugar en que hubiera fallecido, siempre que estuvieran en España, a elección del solicitante. También podrá elegir a un Notario de un distrito colindante a los anteriores. En defecto de todos ellos, será competente el Notario del lugar del domicilio del requirente".

${ }^{93}$ A. Fernández-Tresgerres García, Las sucesiones mortis causa en Europa. Estudio del Reglamento $n^{\circ}$. 650/2012, Aranazadi, Pamplona, 2016, pp. 466-468.

${ }^{94} \mathrm{El}$ art. 843 CC señala de forma literal: "Salvo confirmación expresa de todos los hijos o descendientes la partición a que se refieren los dos artículos anteriores requerirá aprobación por el Secretario judicial o Notario". Mientras que el art. 1057 establece de forma textual: “(...) No habiendo testamento, contador-partidor en él designado o vacante el cargo, el Secretario
} 
dores y la aprobación de la partición son llevadas a cabo por los Secretarios judiciales, como actúan por mandato judicial, están sometidas a las reglas de competencia judicial internacional, como los jueces ${ }^{95}$.

En cualquier caso, esta disparidad de criterios para la atribución de la competencia a los notarios según qué actos, se produce si se sigue la línea interpretativa del art. 64 del Reglamento sucesorio realizada por R. CRÔNE y P. WAUTELET, que en mi opinión es la más acertada y se adapta mejor a los fines del Reglamento ${ }^{96}$.

32. Competencia territorial en España para expedición por notario del certificado sucesorio europeo. Así pues, como en un gran número de Estados miembros, los notarios españoles son considerados autoridades competentes para expedir certificados sucesorios europeos (art. 78.1.c) Reglamento (UE) 650/2012). Las medidas 14 a 17 de las implantadas para facilitar la aplicación en España del Reglamento 650/2012, según la DF 26 de la LEC, introducida por la DF $2^{\circ}$ de la Ley 29/2015, de cooperación jurídica internacional en materia civil, se refieren a la "expedición por notario del certificado sucesorio europeo"97.

Según la medida 14 de las implantadas en España para aplicar el Reglamento (UE) 650/2012 el procedimiento para la expedición del certificado por notario es el siguiente:

$\left.1^{\circ}\right)$ Previa solicitud, compete al notario que declare la sucesión o alguno de sus elementos o a quien legalmente le sustituya o suceda en su protocolo, la expedición del certificado previsto en el artículo 62 del Reglamento 650/2012, debiendo para ello usar el formulario al que se refiere el artículo 67 del mismo Reglamento. La solicitud de la expedición de un certificado sucesorio podrá presentarse mediante el formulario previsto en el artículo 65.2 del mismo Reglamento.

$\left.2^{\circ}\right)$ De dicha expedición del certificado sucesorio europeo, que tendrá el carácter de documento público conforme al artículo 17 de la Ley del Notariado de 28 de mayo de 1862, se dejará constancia mediante nota en la matriz de la escritura que sustancie el acto o negocio, a la que se incorporará el original del certificado, entregándose copia auténtica al solicitante. Si no fuera posible la incorporación a la matriz, se relacionará, mediante nota, el acta posterior a la que deberá ser incorporado el original del certificado.

33. Para determinar el notario español territorialmente competente para expedir el certificado sucesorio europeo se debe realizar una precisión, que está en línea con los actos en las que el notario ejerce funciones jurisdiccionales, y así se ha notificado a la Comisión. Se debe distinguir entre si la expedición del certificado sucesorio europeo deriva de un expediente de jurisdicción voluntaria o si no deriva de un expediente de jurisdicción voluntaria ${ }^{98}$ :

a) Si la expedición del certificado sucesorio europeo deriva de un expediente de jurisdicción voluntaria -declaraciones de herederos hasta cuarto grado; presentación, adveración y apertura de tes-

\footnotetext{
judicial o el Notario, a petición de herederos y legatarios que representen, al menos, el 50 por 100 del haber hereditario, y con citación de los demás interesados, si su domicilio fuere conocido, podrá nombrar un contador-partidor dativo, según las reglas que la Ley de Enjuiciamiento Civil y del Notariado establecen para la designación de peritos. La partición así realizada requerirá aprobación del Secretario judicial o del Notario, salvo confirmación expresa de todos los herederos y legatarios. Lo dispuesto en este artículo y en el anterior se observará aunque entre los coherederos haya alguno sujeto a patria potestad, tutela o curatela; pero el contador-partidor deberá en estos casos inventariar los bienes de la herencia, con citación de los representantes legales o curadores de dichas personas".

${ }^{5}$ A. Fernández-Tresgerres García, Las sucesiones mortis causa en Europa. Estudio del Reglamento $n^{o}$. 650/2012, Aranazadi, Pamplona, 2016, pp. 466-468.

${ }^{96} \mathrm{Si}$, por el contrario, se sigue la otra línea interpretativa, todas las autoridades señaladas por los Estados miembros para la expedición de los certificados sucesorio europeos, que en virtud del Derechio nacional sean competentes para sustanciar las sucesiones mortis causa, como son los notarios, deberán respetar las normas de competencia internacional del Reglamento (UE) 650/2012 y no podrán declararse competentes por sus normas de producción interna para la expedición de tales certificados.

${ }^{97}$ E. Castellanos Ruiz, "Sucesión Hereditaria. El Reglamento Sucesorio Europeo", en A.-L. Calvo Caravaca/J. Carrascosa González (dirs.), Derecho Internacional Privado, Volumen II, Comares, Granada, 2018, p. 691.

${ }^{98}$ E. Castellanos Ruiz, "Sucesión Hereditaria. El Reglamento Sucesorio Europeo", en A.-L. Calvo Caravaca/J. Carrascosa GonZÁlez (dirs.), Derecho Internacional Privado, Volumen II, Comares, Granada, 2018, p. 691.
} 
tamentos ológrafos, cerrados y especiales; las actuaciones relativas a los contadores partidores, aprobación de la partición...- el art. 55 y ss. de la Ley del Notariado de 1862 modificado por la Disposición Final undécima de la Ley 15/2015 de la Jurisdicción Voluntaria, señala el concreto notario español competente según la normativa interna española del Notariado, pues como señala el art. 2 Reglamento 650/2012, el Reglamento sucesorio no afecta a las competencias de las autoridades -dicho instrumento internacional se refiere implícitamene a competencias territoriales-, en este caso de los notarios, de los Estados miembros en materia de sucesiones. Así será competente el notario competente para actuar en el lugar en que hubiera tenido el causante su último domicilio o residencia habitual, o donde estuviere la mayor parte de su patrimonio, o en el lugar en que hubiera fallecido, siempre que estuvieran en España, a elección del solicitante. También podrá elegir a un notario de un distrito colindante a los anteriores. En defecto de todos ellos, será competente el notario del lugar del domicilio del requirente.

b) Si la expedición del certificado sucesorio europeo no deriva de un expediente de jurisdicción voluntaria -aceptación de la herencia sin más, la entrega de legado, adjudicación de la herencia...- rige la regla de la libre elección del notario. No hay unos criterios para determinar el ámbito de competencia territorial del notario.

\section{Relación entre el art. 64 y el art. 4 del Reglamento (UE) 650/2012}

34. Volviendo al asunto Vincent Pierre Oberle, la interpretación sistemática del Abogado General se produce porque según el órgano jurisdiccional remitente -además de los Gobiernos alemán y francés-, al haber incluido el art. 64 dentro del Reglamento (UE) 650/2012, se puede deducir que el art. 4 de este Reglamento no atribuye la competencia en relación a los procedimientos de expedición de certificados sucesorios nacionales ${ }^{99}$. Para los Gobiernos alemán y portugués, si esto fuese así, la inclusión del art. 64 del Reglamento sería superflua y la competencia respecto de los procedimientos de expedición del certificado sucesorio europeo debería determinarse en virtud del art. 4 del Reglamento. Esta postura se fundamenta en la hipótesis de que los certificados sucesorios europeos y nacionales son instrumentos de naturaleza idéntica o al menos similar ${ }^{100}$.

35. La postura de la Comisión es diferente pues considera que el art. 64 del Reglamento (UE) 650/2012 constituye una lex specialis frente al art. 4 de este Reglamento. Esta misma posición también adopta el Gobierno polaco ${ }^{101}$.

En opinión del Abogado General Sr. M. Szpunar, los Gobiernos alemán y portugués parece que no comprenden correctamente la función que desempeña el art. 64 en el sistema de normas establecidas por el Reglamento (UE) 650/2012 102 .

En primer lugar, los certificados sucesorios nacionales son instrumentos que se regulan en virtud de la legislación interna de cada Estado miembro, mientras que el certificado sucesorio europeo es un instrumento nuevo de la legislación de la Unión ${ }^{103}$. Por lo tanto, se tenía que establecer un régimen jurídico autónomo relativo al certificado sucesorio europeo, con el fin de garantizar su aplicación uniforme en todos los Estados miembros.

${ }^{99}$ Conclusiones del Abogado General Sr. M. Szpunar, presentadas el 22 de febrero de 2018, Vincent Pierre Oberle, C-20/17, ECLI:EU:C:2018:89, apartado 77.

${ }^{100}$ Ibidem, apartado 86. Aunque algunos de los gobiernos sí que han manifestado su postura en relación a ellos, pero la Comisión ha indicado que son los Estados miembros los que deben decidir de forma autónoma quiénes tienen que expedir los certificados sucesorios nacionales. Eso sí, el Estado miembro debe aceptar los efectos que produce esta elección cuando elige a los órganos jurisdiccionales para que desempeñen esta función, como sucede en Alemania (Conclusiones del Abogado General Sr. M. Szpunar, presentadas el 22 de febrero de 2018, Vincent Pierre Oberle, C-20/17, ECLI:EU:C:2018:89, apartado 49).

${ }^{101}$ Conclusiones del Abogado General Sr. M. Szpunar, presentadas el 22 de febrero de 2018, Vincent Pierre Oberle, C-20/17, ECLI:EU:C:2018:89, apartado 87.

${ }^{102}$ Ibidem, apartado 88.

103 Idem, apartado 89. 
Es importante destacar en relación al certificado sucesorio europeo que el legislador de la Unión no predeterminó la naturaleza jurídica del mismo. Por lo tanto, no se puede determinar si este certificado constituye una "resolución" (art. 3.1.g) Reglamento (UE) 650/2012); un "documento público" (art. 3.1.i) Reglamento (UE) 650/2012); o ninguna de estas categorías ${ }^{104}$.

36. En segundo lugar, el art. 64 del Reglamento (UE) 650/2012 no reproduce el contenido del art. 4, pero atribuye la competencia respecto de los procedimientos de expedición del certificado sucesorio europeo por la remisión a determinadas disposiciones del capítulo II: arts. 4, 7, 10 y 11 de este Reglamento ${ }^{105}$.

37. En tercer lugar, el art. 64 del Reglamento (UE) 650/2012 incluye dentro del ámbito de aplicación de las disposiciones de competencia no solo a los "tribunales" en el sentido del art. 3.2, sino también a "otras autoridades" que en virtud del Derecho nacional son competentes para sustanciar sucesiones mortis causa de este Reglamento, aunque estas no cumpla con los requisitos previstos en el art. 3.2 del Reglamento sucesorio ${ }^{106}$.

En mi opinión, de esta última aseveración realizada por el Abogado General, podría deducirse que cuando los Estados miembros comuniquen a la Comisión que los notarios son "otra autoridad" para emitir los certificados sucesorios europeos, estos no tienen que respetar las normas de competencia internacional, sino que su competencia deriva del derecho nacional del Estado miembro en cuestión. Por lo tanto, estaría en consonancia con la línea interpretativa de parte de la doctrina antes señalada, entre los que se encuentran R. CRÔNE y P. WAUTELET, con respecto a las normas de competencia de los notarios y de los órganos judiciales para la expedición del certificado sucesorio europeo ${ }^{107}$.

38. En cualquier caso, a la luz de las explicaciones anteriores, el Sr. M. Szpunar sostiene que no se puede deducir como consecuencia de la existencia del art. 64 del Reglamento (UE) 650/2012, que el art. 4 de este Reglamento no es aplicable a los procedimientos de expedición de los certificados sucesorios nacionales ${ }^{108}$.

Analizada la competencia internacional en materia de expedición de certificados sucesorios europeos, se estudiará la competencia internacional en materia de expedición de certificados sucesorios nacionales, y resolver así la cuestión prejudicial planteada en relación con el asunto Vincent Pierre Oberle.

\section{Competencia internacional en materia de expedición de certificados sucesorios nacionales}

39. Para estudiar la competencia internacional en materia de expedición de certificados sucesorios nacionales, se va a analizar la Sentencia del TJUE 21 junio 2018, Vincent Pierre Oberle, C-20/17, porque es la primera sentencia en la que se aborda esta cuestión, como consecuencia de la entrada en vigor del Reglamento (UE) 650/2012 ${ }^{109}$. En este sentido, revisten especial relevancia las interpretaciones sobre determinados conceptos, así como otras observaciones, que el Abogado General Sr. M. Szpunar, realiza en sus Conclusiones sobre dicho asunto.

104 Idem, apartado 90.

105 Idem, apartado 91.

106 Idem, apartado 92.

107 Vid. R. Crône, "Le certificat succesoral européen", en G. Khairallah/M. Revillard, Perspectives du droit des successions européenes et internationales, Étude de la proposition de Règlement du 14 octobre 2009, Defrénois, Paris, 2010, pp. 163-165; P. Wautelet, “Article 3: Definitions” en A. Bonomi/P. Wautelet/I. Pretelli/A. Öztürk, Le droit européen des successions. Commentaire du Règlement $n^{\circ}$ 650/2012 du 4 juillet 2012, 2a ed., Bruylant, Bruxelles, 2016 , p. 171.

108 Conclusiones del Abogado General Sr. M. Szpunar, presentadas el 22 de febrero de 2018, Vincent Pierre Oberle, C-20/17, ECLI:EU:C:2018:89, apartado 93.

109 Existe otra sentencia posterior, que aborda algunos aspectos concretos en relación a la competencia en materia de certificados sucesorios nacionales (STJUE 23 mayo 2019, WB c Notariusz Przemysława Bac, C-658/17, ECLI:EU:C:2019:444). Sin embargo, el Abogado General Sr. Y. Bot en la sentencia de 23 de mayo de 2019 utiliza la interpretación de diversos conceptos, como por ejemplo el concepto de "resolución", añadiendo las precisiones terminológicas al caso concreto, de las Conclusiones del asunto Vincent Pierre Oberle (Conclusiones del Abogado General Sr. Y. Bot, presentadas el 28 de febrero de 2019 , WB $c$. Notariusz Przemystawa Bac, C-658/17, ECLI:EU:C:2019:166). 
Por último, en este apartado se explicarán las conclusiones que pueden extraerse de la Sentencia sobre el asunto Vincent Pierre Oberle.

\section{Análisis de la Sentencia del TJUE 21 junio 2018, Vincent Pierre Oberle, C-20/17}

40. Para realizar un análisis de dicha sentencia, se va a indicar en primer lugar, cuáles son los hechos que dieron lugar a la cuestión prejudicial. En segundo lugar, se explicará por qué el Abogado General ha llegado a la conclucisón de que los certificados sucesorios nacionales se encuentran dentro del ámbito de aplicación del Reglamento (UE) 650/2012.

Por último, se estudiará la norma que, en el caso planteado, determina la competencia internacional en materia de expedición de los certificados sucesorios nacionales: el art. 4 del Reglamento 650/2012; y para ello se tratarán diversos aspectos de forma separada, como son la postura de las partes o la interpretación teleológica o histórica que hace el Abogado General en sus Conclusiones al asunto Vincent Pierre Oberle.

\section{A) Hechos y cuestión prejudicial}

41. El Sr. Adrien Théodore Oberle, ciudadano francés que tenía su última residencia habitual en Francia, falleció el 28 de febrero de 2015, dejando dos hijos. Uno de ellos es el Sr. Vincent Pierre Oberle, que es el demandante en el procedimiento seguido ante el órgano jurisdiccional remitente. Se debe destacar que los elementos patrimoniales de su herencia se encontraban en Francia y en Alemania ${ }^{110}$.

Así pues, el órgano jurisdiccional francés expidió un certificado sucesorio nacional que constataba que el Sr. Vincent Pierre Oberle y su hermano heredaban del difunto en dos partes iguales. A continuación, el demandante solicitó al Amtsgericht Schöneberg (Tribunal de lo Civil y Penal de Schöneberg) -por ser el tribunal competente en virtud de las normas de producción interna alemanas- la expedición de un certificado sucesorio nacional de objeto limitado a la parte de la herencia situada en Alemania. Este certificado debía constatar que el Sr. Vincent Pierre Oberle y su hermano heredaban a partes iguales los bienes del casusante, en virtud del Derecho francés ${ }^{111}$.

42. Sin embargo, el Amtsgerich Schöneberg (Tribunal de lo Civil y Penal de Schöneberg) se declaró incompetente para expedir el certificado sucesorio nacional en virtud de los artículos 4 y 15 del Reglamento (UE) 650/2012. Según dicho órgano jurisdiccional, las disposiciones del Derecho alemán no pueden decidir sobre la competencia internacional respecto del procedimiento relativo a la solicitud del Sr. Vincent Pierre Oberle. Esto implica que son los órganos jurisdiccionales franceses, por ser los del Estado miembro de la residencia habitual del difunto en el momento del fallecimiento, y no los órganos jurisdiccionales alemanes, los competentes para resolver sobre la totalidad de la sucesión, incluso con respecto a la solicitud del Sr. Vincent Pierre Oberle ${ }^{112}$.

Así que, el Sr. Vicente Pierre Oberle recurrió la resolución del Amtsgerich Schöneberg (Tribunal de lo Civil y Penal de Schöneberg) ante el órgano jurisdiccional remitente ${ }^{113}$.

43. El órgano jurisdiccional remitente por su parte, considera que el Amtsgericht Schöneberg (Tribunal de lo Civil y Penal de Schöneberg) tiene competencia internacional para expedir el certificado sucesorio de alcance limitado solicitado por el Sr. Oberle, puesto que existen bienes hereditarios en territorio alemán, de conformidad con las normas de producción interna alemanas ${ }^{114}$.

\footnotetext{
${ }^{110}$ STJUE 21 junio 2018, Vincent Pierre Oberle, C-20/17, ECLI:EU:C:2018:485, apartado 19.

${ }^{111}$ Ibidem, apartados 20-21.

${ }^{112}$ Idem, apartado 22.

${ }^{113}$ Idem, apartado 23.

${ }^{114}$ Idem, apartado 24
} 
Tampoco resulta claro en opinión del órgano jurisdiccional remitente que haya sido voluntad del legislador de la Unión regular de modo exhaustivo, mediante las disposiciones del capítulo II del Reglamento (UE) 650/2012, la competencia internacional en materia de expedición de los certificados sucesorios nacionales, como sí que lo hizo, en relación con el certificado sucesorio europeo ${ }^{115}$. Y si fuese así, no tendría sentido que el legislador de la Unión previese una disposición específica a este respecto, esto es, el art. 64.1 de dicho Reglamento; pudiendo en todo caso, haber establecido una norma específica que regulase la competencia de los certificados sucesorios nacionales ${ }^{116}$.

Además, el órgano jurisdiccional remitente considera que el Amtsgericht Schöneberg (Tribunal de lo Civil y Penal de Schöneberg) incurrió en error al considerar que en este caso se aplicaba la norma del art. 4 del Reglamento (UE) 650/2012. En su opinión, la competencia general de los tribunales del Estado miembro en cuyo territorio tuviera el causante su residencia habitual para "resolver sobre la totalidad de la sucesión", sólo es de aplicación cuando se trata de la adopción de resoluciones judiciales; pero los certificados sucesorios nacionales no son resoluciones de este tipo. Es más, estos certificados se expiden al finalizar un procedimiento de jurisdicción voluntaria y la resolución de expedición del certificado contiene únicamente constataciones de hecho y no es susceptible de adquirir fuerza de cosa juzgada ${ }^{117}$.

44. Así pues, el Kammergericht Berlin (Tribunal Superior Regional de lo Civil y Penal de Berlín) decidió suspender el procedimiento y plantear al Tribunal de Justicia la siguiente cuestión prejudicial ${ }^{118}$ :

"¿Debe interpretarse el articulo 4 del Reglamento [n.o 650/2012] en el sentido de que en él se determina también la competencia internacional exclusiva para la expedición, en los Estados miembros, del certificado sucesorio nacional no sustituido por el certificado sucesorio europeo (véase el artículo 62, apartado 3, del Reglamento n.o 650/2012), con la consecuencia de que son inoperantes, por infringir el Derecho de la Unión, de rango superior, las disposiciones contrarias del legislador nacional relativas a la competencia internacional para la expedición de los certificados sucesorios nacionales, como sucede en Alemania con el artículo 105 de la [FamFG])?"

45. Tal y como señala el Abogado General Sr. M. Szpunar, la cuestión prejudicial ha sido formulada de tal manera que puede sugerir que el órgano jurisdiccional remitente pretende aclarar si el art. 4 del Reglamento (UE) 650/2012 atribuye una "competencia exclusiva" en relación con los procedimientos de expedición de los certificados sucesorios nacionales ${ }^{119}$.

Sin embargo, el Abogado General considera que para responder a la cuestión prejudicial no es relevante determinar si el art. 4 del Reglamento (UE) 650/2012 atribuye "competencia exclusiva", ya que los Estados miembros no pueden modificar las normas de competencia de la Unión por medio de disposiciones nacionales, aunque tales normas se refieran a la competencia no exclusiva ${ }^{120}$.

46. A través de la cuestión prejudicial, como ya se ha indicado con anterioridad, el órgano jurisdiccional remitente solicita fundamentalmente que se determine si el art. 4 del Reglamento (UE) 650/2012 atribuye la competencia con respecto a los procedimientos de expedición de los certificados sucesorios nacionales ${ }^{121}$.

Para responder a la cuestión prejudicial en primer lugar, se va a estudiar si los certificados sucesorios nacionales y los procedimientos que se refieren a ellos se encuentran comprendidos dentro el ámbito de aplicación del Reglamento (UE) 650/2012.

\footnotetext{
${ }^{115}$ Idem, apartado 25.

${ }_{116}$ Idem, apartado 26.

${ }^{117}$ Idem, apartado 27.

118 Idem, apartado 28.

119 Conclusiones del Abogado General Sr. M. Szpunar, presentadas el 22 de febrero de 2018, Vincent Pierre Oberle, C-20/17, ECLI:EU:C:2018:89, apartado 17.

${ }^{120}$ Ibidem, apartado 20.

${ }^{121}$ Idem, apartado 21.
} 


\section{B) Los certificados sucesorios nacionales como objeto del ámbito de aplicación del Reglamento (UE) 650/2012}

47. De acuerdo con el Abogado General Sr. M. Szpunar de los estudios de Derecho comparado se puede afirmar que los certificados sucesorios nacionales utilizados en algunos Estados miembros presentan profundas divergencias entre sí ${ }^{122}$.

Así en función del órgano que expide el certificado sucesorio nacional, se pueden distinguir tres categorías de certificados: los certificados judiciales, los certificados notariales y las declaraciones pri$\operatorname{vadas}^{123}$. Sin embargo, este criterio puede no resultar adecuado para identificar los certificados sucesorios nacionales, puesto que en el ámbito de estas categorías existen profundas diferencias entre las soluciones adoptadas en algunos Estados miembros ${ }^{124}$.

En cualquier caso, se puede reconocer que en los certificados sucesorios nacionales se hace constar información referida a la sucesión de una determinada persona, incluida la información relativa a personas a las que se le otorgan determinadas facultades en relación con la muerte del causante ${ }^{125}$. De manera que dichos certificados nacionales normalmente permiten probar dichas circunstancias ante las autoridades públicas y frente a terceros ${ }^{126}$.

48. En la redacción del Reglamento (UE) 650/2012 no se utiliza nunca la expresión "certificado sucesorio nacional". Sin embargo, sí que existe en el Reglamento la expresión siguiente: "documentos internos empleados en los Estados miembros para fines similares" a los del certificado sucesorio europeo; y que no quedarán sustituidos por el certificado sucesorio europeo ${ }^{127}$.

En este sentido, el órgano jurisdiccional remitente también considera que el certificado sucesorio nacional aludido en el procedimiento principal es un "documento interno" en el sentido del art. 62.3 del Reglamento (UE) 650/2012. Por lo tanto, la cuestión prejudicial se refiere al "certificado sucesorio nacional no sustituido por el certificado sucesorio europeo". Así pues, tal y como señala el Abogado General, el fondo de la cuestión se remite, en definitiva, al art. 62.3 del Reglamento ${ }^{128}$.

49. La doctrina por su parte, ha sostenido que la primera frase del art. 62.3 determina la relación del certificado sucesorio europeo respecto de los certificados sucesorios nacionales, de forma que éste no fue redactado para excluir los certificados sucesorios nacionales del ámbito de aplicación de las normas de competencia del Reglamento (UE) 650/2012 ${ }^{129}$.

${ }^{122}$ Idem, apartado 23

123 J. Basedow, A. Dutta, C. BAuER et AL. (Max Planck Institute for Comparative and International Private Law), "Proposal for a Regulation of the European Parliament and of the Council on jurisdiction, appicable law, recognition and enforcement of decisions and authentic instruments in matters of succession and the creation of a European Certificate of Succession", Rabels Zeitschrift für ausländisches und internationales Privatrecht, vol. 74, n. ${ }^{\circ}$ 266, 2010.

${ }^{124}$ A. DAvì/A. ZANOBEtTI, "Il nuovo diritto internazionale privato delle successioni nell'Unione Europea", Cuadernos de Derecho Transnacional, (Octubre 2013), Vol. 5, № 2, pp. 132-134; P. WAUTELET, “Chapitre VI: Certificat Successoral Européen” en A. Bonomi/P. Wautelet/I. Pretelli/A. ÖZtürk, Le droit européen des successions. Commentaire du Règlement no 650/2012 du 4 juillet 2012, 2a ed., Bruylant, Bruxelles, 2016, pp. 772-775; D. STAMATIADIS, “Chapter VI: European Certificate of Succession”, en H. Pamboukis (ed.), EU Succession Regulation N. 650/2012: A Commentary, C.H. Beck/Hart Publishing, Oxford, 2017, pp. 580-587.

125 Conclusiones del Abogado General Sr. M. Szpunar, presentadas el 22 de febrero de 2018, Vincent Pierre Oberle, C-20/17, ECLI:EU:C:2018:89, apartados 23-25.

126 P. Wautelet, "Chapitre VI: Certificat Successoral Européen” en A. Bonomi/P. Wautelet/I. Pretelli/A. Öztürk, Le droit européen des successions. Commentaire du Règlement $n^{o}$ 650/2012 du 4 juillet 2012, 2a ed., Bruylant, Bruxelles, 2016, pp. $772-775$.

${ }^{127}$ Art. 62.3 y Considerando (67) Reglamento (UE) 650/2012 (Conclusiones del Abogado General Sr. M. Szpunar, presentadas el 22 de febrero de 2018, Vincent Pierre Oberle, C-20/17, ECLI:EU:C:2018:89, apartados 26-27).

${ }^{128}$ Conclusiones del Abogado General Sr. M. Szpunar, presentadas el 22 de febrero de 2018, Vincent Pierre Oberle, C-20/17, ECLI:EU:C:2018:89, apartado 28. En el art. 1.2 del Reglamento (UE) 650/2012 no se han incluido preceptos que puedan sugerir que no están comprendidos en el ámbito de aplicación del mismo, los demás instrumentos jurídicos y procedimientos que se refieren a las sucesiones por causa de muerte (Considerando (69), segunda frase), entre los que se encontrarían los certificados sucesorios nacionales y los procedimientos relativos a ellos (Conclusiones del Abogado General Sr. M. Szpunar, presentadas el 22 de febrero de 2018, Vincent Pierre Oberle, C-20/17, ECLI:EU:C:2018:89, apartados 32-34).

${ }^{129}$ Art. 62.3 Reglamento (UE) 650/2012: "El certificado no sustituirá a los documentos internos empleados en los Estados miembros para fines similares”. Vid. B. KreßE, "Chapter VI: European Certificate of Succession”, en A.-L. Calvo CaravaCa/A. 
Por su parte, el Abogado General Sr. M. Szpunar sigue esta misma línea interpretativa, de forma que del art. 62.2 del Reglamento sucesorio se deduce que no será obligatoria la utilización del certificado sucesorio europeo $^{130}$. A la luz de la segunda frase del Considerando (69), las personas con derecho a solicitar un certificado sucesorio europeo no deben estar obligadas a ello ${ }^{131}$. Estas personas pueden recurrir "a los demás instrumentos que el presente Reglamento pone a su disposición (resoluciones, documentos

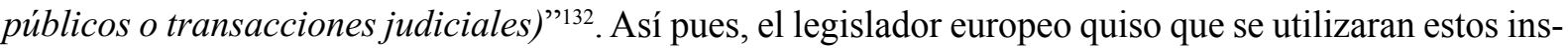
trumentos, entre los que está el certificado sucesorio nacional, para los mismos fines para los que puede utilizarse el certificado sucesorio europeo ${ }^{133}$.

Tampoco lleva a una postura diferente, el hecho de que los certificados sucesorios nacionales se destinen al tráfico interior en un Estado miembro determinado, tal y como se deduce de la interpretación del art. 62.3 del Reglamento (UE) 650/2012 ${ }^{134}$. En este sentido, el certificado sucesorio europeo "no sustituirá" a los certificados sucesorios nacionales, puesto que el certificado sucesorio europeo se expide para ser utilizado en otros Estados miembros que no sean el Estado cuyos órganos son competentes para expedir dicho certificado europeo (art. 62.1 Reglamento (UE) 650/2012) ${ }^{135}$. Esto es así, siempre y cuando, las normas de competencia internacional no sean las mismas para la expedición de ambos tipos de certificados; porque si son las mismas, tal y como se desprende del fallo de la Sentencia en el asunto Vincent Pierre Oberle, las personas van a preferir solicitar el certificado sucesorio europeo, para reducir los costes de tener que trasladarse a cada uno de los Estados miembros que sean competentes para solicitar los correspondientes certificados nacionales.

50. En resumen, el ámbito de aplicación del Reglamento (UE) 650/2012 ha sido delimitado por el legislador de la Unión, de tal modo que, tanto en lo relativo a las normas de conflicto como a las normas de competencia, éste abarca la totalidad de las materias relacionadas con la sucesión por causa de muerte; siempre y cuando dicho Reglamento no prevea una exclusión relativa a determinadas materias. De forma, que tal y como señala el Abogado General en sus Conclusiones, no existe en el Reglamento (UE) 650/2012 una exclusión explícita de los certificados sucesorios nacionales y de los procedimientos en relación a los mismos ${ }^{136}$.

Así pues, el Sr. M. Szpunar considera que aquellos instrumentos jurídicos como son los certificados sucesorios nacionales y los procedimientos que se refieren a ellos se encuentran dentro del ámbito de aplicación del Reglamento (UE) 650/2012 ${ }^{137}$.

Davi/H.-P. Mansel (eds.), The EU Succession Regulation: a commentary, Cambridge University Press, Cambridge, 2016, p. 681; D. Stamatiadis, "Chapter VI: European Certificate of Succession”, en H. Pamboukis (ed.), EU Succession Regulation $N^{\circ}$. 650/2012: A Commentary, C.H. Beck/Hart Publishing, Oxford, 2017, p. 591.

${ }^{130}$ Sobre la no obligatoriedad del certificado sucesorio europeo se volverá cuando se aborde la interpretación teleológica del Abogado General en sus Conclusiones al asunto Vincent Pierre Oberle.

${ }_{131}$ Conclusiones del Abogado General Sr. M. Szpunar, presentadas el 22 de febrero de 2018, Vincent Pierre Oberle, C-20/17, ECLI:EU:C:2018:89, apartado 37.

${ }^{132}$ Considerando (69) Reglamento (UE) 650/2012.

${ }^{133}$ En relación al carácter alternativo de ambos certificados sucesorios -el europeo y el nacional- vid., A. DAvì/A. ZANOBETTI, "Il nuovo diritto internazionale privato delle successioni nell'Unione Europea", Cuadernos de Derecho Transnacional, (Octubre 2013), Vol. 5, No 2, p. 134; P. Wautelet, "Chapitre VI: Certificat Successoral Européen" en A. Bonomi/P. Wautelet/I. Pretelli/A. Öztürk, Le droit européen des successions. Commentaire du Règlement no 650/2012 du 4 juillet 2012, $2^{\mathrm{a}}$ ed., Bruylant, Bruxelles, 2016, pp. 780-791; B. KreßE, "Chapter VI: European Certificate of Succession", en A.-L. Calvo CaravaCA/A. Davi/H.-P. Mansel (eds.), The EU Succession Regulation: a commentary, Cambridge University Press, Cambridge, 2016, pp. 680-685; D. Stamatiadis, "Chapter VI: European Certificate of Succession”, en H. Pamboukis (ed.), EU Succession Regulation $N^{\circ}$. 650/2012: A Commentary, C.H. Beck/Hart Publishing, Oxford, 2017, pp. 590-593. El Abogado General Sr. M. Szpunar señala la posibilidad, sobre la que tiene dudas, de acudir a la diferenciación de ambos certificados en función de la finalidad de los certificados sucesorios, pero nada ha indicado el legislador de la Unión al respecto (Conclusiones del Abogado General Sr. M. Szpunar, presentadas el 22 de febrero de 2018, Vincent Pierre Oberle, C-20/17, ECLI:EU:C:2018:89, apartado 39).

${ }_{134}$ Conclusiones del Abogado General Sr. M. Szpunar, presentadas el 22 de febrero de 2018, Vincent Pierre Oberle, C-20/17, ECLI:EU:C:2018:89, apartado 38.

${ }^{135}$ Ibidem, apartado 38.

${ }^{136}$ Idem, apartado 40.

${ }^{137}$ Idem, apartado 41. 
51. Efectivamente en mi opinión, de la redacción del Reglamento (UE) 650/2012 no se puede interpretar que los certificados sucesorios nacionales estén excluídos del ámbito de aplicación del mismo. Sin embargo, sobre todo en lo que afecta a la coexistencia de ambos certificados sucesorios -el europeo y el nacional- debería haberse adoptado por cualquiera de estas opciones: a) la exclusión explícita de los certificados sucesorios nacionales, dejando a las normas de producción interna de los Estados miembros su regulación; b) la inclusión dentro del ámbito de aplicación del Reglamento (UE) 650/2012, pero añadiendo un precepto en el que se indique que los certificados sucesorios nacionales quedarán regulados por las normas de producción interna; c) la inclusión en el ámbito de aplicación del Reglamento sucesorio de los certificados sucesorios nacionales, mediante una regulación específica, como la que ya existe para las certificados sucesorios europeos, y haber distinguido claramente las funciones o la finalidad de cada tipo de certificado; d) la inclusión en el ámbito de aplicación del Reglamento (UE) 650/2012 de los certificados sucesorios nacionales, mediante la eliminación de las normas de competencia de los certificados sucesorios europeos, con lo cual regirían las normas de competencia general para ambos tipos de certificados. Esta última solución propuesta es la que, según los Gobiernos alemán y portugués, debería haberse realizado si se hubiesen querido incluir los certificados sucesorios nacionales en el ámbito de aplicación del Reglamento (UE) 650/2012 $2^{138}$.

En ese sentido, mediante la inclusión de los procedimientos en relación a la expedición de los certificados nacionales en el ámbito de aplicación del Reglamento (UE) 650/2012, se puede llegar a contradecir la norma que señala que el uso del certificado europeo es alternativo al certificado nacional ${ }^{139}$. Se volverá a abordar esta cuestión cuando se trate el asunto de la no obligatoriedad del certificado sucesorio europeo, en el apartado correspondiente a la interpretación teleológica del Abogado General en sus Conclusiones al asunto Vincent Pierre Oberle.

\section{C) La competencia en materia de expedición de los certificados sucesorios nacionales: el art. 4 del Reglamento (UE) 650/2012}

52. Una vez que se ha interpretado que la expedición de los certificados sucesorios nacionales y los procedimientos relativos a los mismos entran dentro del ámbito de aplicación del Reglamento (UE) 650/2012, se debe determinar si el art. 4 de dicho instrumento puede ser de aplicación a la expedición del certificado sucesorio alemán en el asunto Vincent Pierre Oberle. Si la respuesta es afirmativa, el fallo de la sentencia tendrá repercusiones en aquellos Estados miembros en los que existe la posibilidad de que los órganos jurisidiccionales expidan certificados sucesorios nacionales, como ocurre en Alemania.

53. Para el órgano jurisdiccional remitente en el asunto Vincent Pierre Oberle, aunque el art. 4 del Reglamento (UE) 650/2012 fuese de aplicación pues los procedimientos relativos a los certificados sucesorios nacionales entran dentro del ámbito de aplicación de dicho instrumento internacional, esta disposición no resultaría aplicable. El motivo que señala es que el certificado sucesorio nacional al que se refiere el procedimiento principal no constituye una "resolución" en el sentido del Reglamento. En su opinión, aunque la expedición del certificado sucesorio nacional se produce por medio de la expedición de una "resolución", el certificado se extenderá exclusivamente a los antecedentes de hecho, no incorporándese a él ningún elemento que pueda adquirir efecto de cosa juzgada ${ }^{140}$.

${ }^{138}$ Se tratará de nuevo este asunto, en el último apartado, a modo de propuesta para el legislador europeo para futuras modificaciones del Reglamento (UE) 650/2012, pues dada la especial importancia que tiene dicha materia sobre los ciudadanos, es necesario una regulación lo más exhaustiva posible.

139 Vid. en este sentido, M.-J. Castellanos Ruiz, "Competencia internacional”, en A.-L. Calvo Caravaca/J. Carrascosa GonzÁLEZ (dirs.), Litigación Internacional en la Unión Europea (IV): Comentario al Reglamento (UE) núm. 650/2012 del Parlamento Europeo y del Consejo sobre sucesiones mortis causa, Aranzadi, Navarra, 2019, p. 92; I. ANTÓN JuÁrEz, "Certificado Sucesorio Europeo", en A.-L. Calvo Caravaca/J. Carrascosa GonzÁlez (dirs.), Litigación Internacional en la Unión Europea (IV): Comentario al Reglamento (UE) núm. 650/2012 del Parlamento Europeo y del Consejo sobre sucesiones mortis causa, Aranzadi, Navarra, 2019, p. 335.

${ }_{140}$ Conclusiones del Abogado General Sr. M. Szpunar, presentadas el 22 de febrero de 2018, Vincent Pierre Oberle, C-20/17, ECLI:EU:C:2018:89, apartado 44. 
Para ello se tratará este aspecto tan problemático de la "resolución" empezando por la postura de las partes, para seguir con la interpretación teleológica e histórica que realiza el Abogado General en sus Conclusiones al asunto Vincent Pierre Oberle, puesto que la interpretación literal y sistemática en relación con el art. 4 del Reglamento (UE) 650/2012 ya ha sido objeto de análisis.

\section{a) Postura de las partes}

54. Por un lado, los Gobiernos alemán, francés y portugués consideran que el art. 4 del Reglamento (UE) 650/2012 no es de aplicación a los procedimientos relativos a la expedición de los certificados sucesorios nacionales; mientras, por otro lado, el Gobierno polaco y la Comisión mantienen la postura contraria $^{141}$.

55. El Gobierno alemán afirma que el art. 4 del Reglamento (UE) 650/2012 atribuye la competencia respecto de los procedimientos en los que se dictan "resoluciones", naturaleza que no ostenta el certificado sucesorio nacional, del que es objeto la petición de decisión prejudicial. El legislador de la Unión no considera que los certificados sucesorios nacionales sean "resoluciones", puesto que el art. 62.3 del Reglamentos sucesorio los define como "documentos internos". Para el gobierno alemán, el hecho de que la expedición del certificado sucesorio nacional se haga por parte de un órgano jurisdiccional no cambia la calificación de este certificado a la luz del Reglamento (UE) 650/2012 ${ }^{142}$.

En esta línea interpretativa se encuentra el Gobierno francés, que señala que, aunque se puede aceptar como "resolución" el certificado sucesorio expedido en el ejercicio de la función jurisdiccional por parte de un tribunal; sin embargo, "las actuaciones consistentes en la expedición de certificados sucesorios nacionales carecen de tal naturaleza cuando se limitan a constatar un determinado estado de cosas, sin valorarlo y sin que haya la posibilidad de iniciar actuaciones de oficio a este respecto"143.

En opinión del Gobierno portugués, el certificado sucesorio nacional al que se refiere el procedimiento principal -al igual que el certificado sucesorio europeo- debería ser considerado un instrumento de naturaleza híbrida. Esto implicaría que el art. 4 del Reglamento (UE) 650/2012 no sería de aplicación en el procedimiento principal ${ }^{144}$.

56. Sin embargo, para la Comisión son los Estados miembros los que deben decidir de forma autónoma quiénes tienen que expedir los certificados sucesorios nacionales. Eso sí, el Estado miembro debe aceptar los efectos que produce esta elección cuando elige a los órganos jurisdiccionales para que desempeñen esta función, como sucede en Alemania. En ese caso, el certificado sucesorio nacional expedido por un órgano jurisdiccional constituye -como también lo señala el Gobierno polaco- una "resolución" en el sentido del art. 3.1.g) del Reglamento (UE) 650/2012, con independencia de la posición que haya adoptado el Derecho nacional en esta materia ${ }^{145}$.

57. Tal y como señala el Abogado General Sr. M. Szpunar, las partes mencionan la argumentación dual del órgano jurisdiccional remitente, que resume la síntesis de las posturas existentes en la doctrina respecto de la cuestión analizada ${ }^{146}$. Si bien en mi opinión la mayor parte de la doctrina no se ha planteado esta disyuntiva hasta el asunto Vincent Pierre Oberle, sino que se ha limitado a analizar: el ámbito de aplicación del Reglamento sucesorio; las normas de competencia internacional; así como las normas sobre el certificado sucesorio europeo, considerado un nuevo tipo de certificado, diferente al certificado nacional ${ }^{147}$. Sin embargo, no se realiza mención alguna a las normas sobre competencia internacional en

\footnotetext{
141 Ibidem, apartado 45.

142 Idem, apartado 46.

143 Idem, apartado 47.

144 Idem, apartado 48.

145 Idem, apartado 49.

146 Idem, apartado 50.

${ }^{147}$ H. GAudemet-Tallon, “Quelques réflexions sur les propositions concernant la compétence judiciaire, la reconnaissance
} 
materia de expedición de certificados sucesorios nacionales, precisamente porque consideran que están excluidos de forma implícita del ámbito de aplicación del Reglamento (UE).

Existen muy pocos autores que consideran que el Reglamento sucesorio -con la excepción relativa a las medidas cautelares del art. 19 Reglamento (UE) 650/2012-regula la competencia nacional en las sucesiones de modo universal, de forma que sustituye a cualesquiera disposiciones nacionales relativas a estos asuntos ${ }^{148}$.

58. En cuanto a la jursiprudencia, es importante destacar la sentencia del Hanseatisches Oberlandesgericht Hamburg (Tribunal Superior Regional de lo Civil y Penal de Hamburgo, Alemania) de 16 de noviembre de $2016^{149}$. En la misma se señaló que una "resolución" en el sentido del art. 3.1.g) del Reglamento (UE) 650/2012 significa cualquier decisión en asuntos de sucesiones, expedida por un órgano jurisdiccional de un Estado miembro, con independencia del nombre de tal decisión, "y por tanto también el certificado sucesorio" 150 .

Basándose en este argumento, se decidió que el órgano jurisdiccional alemán no era competente para conocer de un procedimiento relativo a la expedición de un certificado sucesorio nacional, en relación a un causante cuya última residencia habitual estuvo en España. En virtud del art. 4 del Reglamento (UE) 650/2012, los tribunales del Estado miembro en el que el causante tuviera su residencia habitual en el momento del fallecimiento tendrán la competencia para resolver sobre la totalidad de la sucesión.

\section{b) Interpretación teleológica del Abogado General en las Conclusiones de la sentencia}

59. Para realizar la interpretación teleológica, el Abogado General en las Conclusiones al asunto Vincent Pierre Oberle compara las conclusiones resultantes de la interpretación sistemática con los fines del Reglamento (UE) 650/2012.

et l'exécution des décisions en matière successorale dans l'Union européenne", en DNotI, Les Successions Internationales dans l'UE, pp. 445-459, disponible en línea en http://www.successions.org/16-Gaudemet-Tallon.pdf (consultado el 1 de diciembre de 2019); P. LAGARDE, "Les principes de base du nouveau règlement européen sur les successions", Revue Critique Droit International Privé, octobre-décembre 2012, pp. 691-732; AA.VV. (sous la direction de G. KhaIRallah/M. RevilLard), Droit européen des successions internationales (Le Règlement du 4 juillet 2012), Defrénois, Paris, 2013; D. Damascelli, Diritto internacionales privato delle successioni a causa di morte, Giuffrè Editore, Milano, 2013; A. DAvi/A. ZANobEtTI, "Il nuovo diritto internazionale privato delle successioni nell'Unione Europea", Cuadernos de Derecho Transnacional, (Octubre 2013), Vol. 5, No 2, pp. 5-139; T. BAllarino, "Il nuovo Regolamento europeo sulle successioni, Rivista di Diritto Internazionale, Gioffrè Editore, Milano, Anno XCVI, Fasc. 4-2013, pp. 1116-1145; M. ReVIILAD, Règlement (UE) Nº. 650/2012 du Parlement Européen et du Conseil du 4 juillet 2012, LexisNexis, S.A., Fasc. 4-2013, pp. 1-27; A. Davì/A. ZANoBEtTI, Il nuovo diritto internazionale privato europeo delle successioni, Giappichelli Editore, Torino, 2014; R.-M. Moura Ramos, Studi in onore de Laura Picchio Forlati - Le nouveau droit international privé des successions de l'union européenne premières réflexions, Ed. Giappichelli, Torino, 2014; A.-L. Calvo Caravaca/A. Davi/H.-P. Mansel (eds.), The EU Succession Regulation: a commentary, Cambridge University Press, Cambridge, 2016; A. Bonomi/P. Wautelet/I. Pretelli/A. Öztürk, Le droit européen des successions. Commentaire du Règlement $n^{\circ}$ 650/2012 du 4 juillet 2012, 2a ed., Bruylant, Bruxelles, 2016; D. STAmatiadis, "Chapter VI: European Certificate of Succession”, en H. Pamboukis (ed.), EU Succession Regulation No. 650/2012: A Commentary, C.H. Beck/Hart Publishing, Oxford, 2017; A.-L. Calvo Caravaca/J. Carrascosa GonzÁlez (dirs.), Litigación Internacional en la Unión Europea (IV): Comentario al Reglamento (UE) núm. 650/2012 del Parlamento Europeo y del Consejo sobre sucesiones mortis causa, Aranzadi, Navarra, 2019; J. CARrascosa GonZÁlez, El Reglamento sucesorio europeo 650/2012 de 4 de julio de 2012. Análisis crítico, Rapid Centro Color, Murcia, 2019.

${ }^{148}$ K. WeItz, "Jurysdykcja krajowa w sprawach spadkowych w świetle rozporządzenia spadkowego", en M. PAZDAN (coord.), Nowe europejskie prawo spadkowe, Wolters Kluwer, Varsovia, 2015, p. 42. Algunos autores otorgan en este contexto una mayor importancia a la calificación del certificado sucesorio nacional y consideran que este constituye una "resolución" en el sentido del Reglamento (UE) 650/2012 (A. BonOmI, "Chapitre II: Competence: Introduction au chapitre II", en A. BonOMI/P. Wautelet/I. Pretelli/A. ÖZtürk, Le droit européen des successions. Commentaire du Règlement no 650/2012 du 4 juillet 2012, $2^{\mathrm{a}}$ ed., Bruylant, Bruxelles, 2016, p. 184).

${ }_{149}$ Sentencia del Hanseatisches Oberlandesgericht Hamburg (Tribunal Superior Regional de lo Civil y Penal de Hamburgo, Alemania) de 16 de noviembre de 2016, 2 W 85/16, Praxis der Freiwilligen Gerichtsbarkeit 2017, Heft 3, p. 129.

${ }^{150}$ Apartado 23 de la Sentencia del Hanseatisches Oberlandesgericht Hamburg (Tribunal Superior Regional de lo Civil y Penal de Hamburgo, Alemania) de 16 de noviembre de 2016, 2 W 85/16, Praxis der Freiwilligen Gerichtsbarkeit 2017, Heft 3, p. 129. 
60. El carácter obligatorio del certificado sucesorio europeo. La doctrina destaca el carácter no obligatorio del certificado sucesorio europeo establecido por el art. 62.2 del Reglamento (UE) 650/2012 $2^{151}$.

Sin embargo, el Gobierno alemán señala que si los procedimientos de expedición de certificados sucesorios nacionales están sujetos a la atribución de la competencia general de art. 4 del Reglamento (UE) 650/2012, esto provocaría que únicamente las autoridades de un Estado miembro podrían expedir certificados sucesorios nacionales; siendo dichas autoridades las competentes también para la expedición del certificado sucesorio europeo ${ }^{152}$. Por lo tanto, según el gobierno alemán, se les estaría imponiendo a los interesados la obligación de solicitar el certificado sucesorio europeo en contra de lo señalado en el art. 62.2 del Reglamento (UE) 650/2012 153 .

En el lado opuesto, el Gobierno polaco considera que es mejor aquella solución que contribuya a un mayor papel del certificado sucesorio europeo ${ }^{154}$.

61. El Abogado General no comparte la postura del Gobierno alemán, según la cual la aplicación de las normas de competencia general a los procedimientos de expedición de los certificados sucesorios nacionales no implica en la práctica que la utilización del certificado sucesorio eurpeo tenga carácter obligatorio $^{155}$.

En su opinión, dicha interpretación del art. 4 del Reglamento (UE) 650/2012 en la práctica no prohíbe a los interesados la posibilidad de obtener certificados sucesorios nacionales en el Estado miembro cuyas autoridades sean competentes para expedir el certificado europeo ${ }^{156}$.

Por otro lado, según el Abogado General, parece que el Gobierno alemán hace una interpretación del art. 62.2 del Reglamento (UE) 650/2012, en el que se aborda la inexistencia de la obligación de utilizar el certificado sucesorio europeo, exclusivamente en el sentido de que establece la relación del certificado sucesorio europeo con respecto a los certificados sucesorios nacionales. Sin embargo, es el art. 62.3 del Reglamento sucesorio el que se refiere exclusivamente a esta cuestión. El art. 62.2 del Reglamento se refiere no solo a los certificados sucesorios nacionales, sino también a cualquiera de los "instrumentos que el presente Reglamento pone a su disposición" de los interesados ${ }^{157}$.

62. Sin embargo, en mi opinión, aunque efectivamente al igual que señala el Abogado General, el certificado sucesorio europeo no tiene carácter obligatorio, en virtud del art. 62.2 del Reglamento (UE) 650/2012, sí que estoy de acuerdo con parte de los argumentos que señala el Gobierno alemán. Así

151 P. Wautelet, "Chapitre VI: Certificat Successoral Européen" en A. Bonomi/P. Wautelet/I. Pretelli/A. Öztürk, Le droit européen des successions. Commentaire du Règlement $n^{\circ}$ 650/2012 du 4 juillet 2012, 2 ${ }^{\mathrm{a}}$ ed., Bruylant, Bruxelles, 2016, pp. 780-791; B. Kreße, "Chapter VI: European Certificate of Succession”, en A.-L. Calvo Caravaca/A. Davi/H.-P. Mansel (eds.), The EU Succession Regulation: a commentary, Cambridge University Press, Cambridge, 2016, pp. 680-685; D. STAMATIADIS, “Chapter VI: European Certificate of Succession”, en H. Pamboukis (ed.), EU Succession Regulation N". 650/2012: A Commentary, C.H. Beck/Hart Publishing, Oxford, 2017, pp. 590-593; C. TOADER, "Primele aplicatii în jurisprudenta Curtii de Justitie a Uniunii Europene ale Regulamentului nr. 650/2012 privind succesiunile europene, cu elemente de drept succesoral comparat", Revista romănă de Drept European, Nr. 1/2018, p. 33.

${ }^{152}$ Conclusiones del Abogado General Sr. M. Szpunar, presentadas el 22 de febrero de 2018, Vincent Pierre Oberle, C-20/17, ECLI:EU:C:2018:89, apartado 95.

${ }^{153}$ Sin embargo, según el Gobierno alemán, en ocasiones, el uso de los certificados sucesorios nacionales expedidos por otros Estados miembros podría implicar más ventajas que la utilización del certificado sucesorio europeo (P. WAUTELET, "Chapitre VI: Certificat Successoral Européen” en A. Bonomi/P. Wautelet/I. Pretelli/A. ÖztürK, Le droit européen des successions. Commentaire du Règlement no 650/2012 du 4 juillet 2012, 2a ed., Bruylant, Bruxelles, 2016, p. 781; B. KRE $\beta$ E, "Chapter VI: European Certificate of Succession", en A.-L. Calvo Caravaca/A. Davi/H.-P. Mansel (eds.), The EU Succession Regulation: a commentary, Cambridge University Press, Cambridge, 2016, pp. 680). Además, se les estaría privando a los interesados de la posibilidad de utilizar los certificados sucesorios nacionales expedidos por los órganos jurisdiccionales de otros Estados miembros, lo cual contradice el objetivo del Reglamento (UE) 650/2012 del Considerando (67) que es la tramitación rápida, ágil y eficiente de las sucesiones transfronterizas (Conclusiones del Abogado General Sr. M. Szpunar, presentadas el 22 de febrero de 2018, Vincent Pierre Oberle, C-20/17, ECLI:EU:C:2018:89, apartado 96).

${ }^{154}$ Conclusiones del Abogado General Sr. M. Szpunar, presentadas el 22 de febrero de 2018, Vincent Pierre Oberle, C-20/17, ECLI:EU:C:2018:89, apartado 97.

155 Ibidem, apartado 98.

${ }^{156} \mathrm{Idem}$, apartado 99.

${ }^{157}$ Considerando (69) (Conclusiones del Abogado General Sr. M. Szpunar, presentadas el 22 de febrero de 2018, Vincent Pierre Oberle, C-20/17, ECLI:EU:C:2018:89, apartado 100). 
pues, si para la expedición de los certificados sucesorios nacionales, se tienen que cumplir las normas de competencia internacional cuando en dicho Estado miembro es un tribunal el que los emite, no se está favoreciendo el que los Estados miembros soliciten la expedición de los certificados nacionales. Todo lo contrario, se está obligando a que por economía conflictual los interesados soliciten un certificado sucesorio europeo ante el tribunal competente tanto para la expedición del certificado sucesorio europeo como el certificado nacional; en vez de tener que ir solicitando diferentes certificados nacionales en Estados con distintas normas sobre competencia internacional para la expedición de dichos certificados ${ }^{158}$.

En consecuencia, no se está obligando -teóricamente- a los interesados a solicitar el certificado sucesorio europeo, pero sí que se está favoreciendo la utilización en mayor medida del certificado sucesorio europeo frente al certificado nacional.

63. Los fines del Reglamento (UE) 650/2012. El fin principal para el que se adoptó el Reglamento sucesorio es conseguir la uniformidad de las normas de conflicto y de competencia aplicables a las sucesiones, en virtud de los Considerandos (7) y (8), tal y como señala el Abogado General ${ }^{159}$.

Pues bien, la aplicación de las normas nacionales de competencia a los procedimientos de expedición de certificados sucesorios nacionales contradice precisamente la tendencia a uniformizar las normas de competencia y de conflicto en el marco de la Unión ${ }^{160}$. Un claro ejemplo son las circunstancias del litigio principal, pues se solicitó al órgano jurisdiccional alemán la expedición de un certificado sucesorio nacional relativo a una sucesión sujeta al Derecho francés, en virtud de las normas nacionales de competencia.

64. Otro de los fines del Reglamento (UE) 650/2012 es el reconocimiento mutuo de las resoluciones dictadas en los Estados miembros en materia de sucesiones, como prevé el Considerando (59), y así contribuir a garantizar el buen funcionamiento de la justicia de la Unión, que señala el Considerando $(34)^{161}$.

Así pues, dicho instrumento ha adoptado unas normas de conflicto uniformizadas en virtud de las cuales se designa la ley aplicable a la totalidad de la sucesión, en virtud del art. 23.1 del Reglamento (UE) 650/2012. Sin embargo, algunas cuestiones relevantes en la tramitación de las sucesiones se regulan en virtud de la ley designada por las normas nacionales de conflicto, tal y como señalan los Considerandos (11) a (13) y (71). Esto provocaría, en definitiva, situaciones en las que las autoridades de algunos Estados miembros expidan instrumentos de tramitación de la sucesión incompatibles entre sí1 ${ }^{162}$.

En la sentencia del asunto Kubicka el Tribunal, el TJUE declaró que es incompatible con los objetivos perseguidos por el Reglamento (UE) 650/2012, una interpretación de las normas del mismo que provoque una "fragmentación de la sucesión" ${ }^{163}$. Aunque en la sentencia del caso Kubicka se hacía referencia a cuestiones relativas al ámbito del estatuto de la herencia; en opinión del Abogado General, esto puede ser utilizado para la interpretación de las normas del Reglamento sucesorio cuando se refieren a otras cuestiones ${ }^{164}$. Precisamente la unidad de la sucesión, era uno de los principios inspiradores -la ratio- de la norma de conflicto española cuando todavía no era de aplicación el Reglamento (UE)

158 Vid. en este sentido, M.-J. Castellanos Ruiz, “Competencia internacional”, en A.-L. Calvo Caravaca/J. Carrascosa GonzÁlez (dirs.), Litigación Internacional en la Unión Europea (IV): Comentario al Reglamento (UE) núm. 650/2012 del Parlamento Europeo y del Consejo sobre sucesiones mortis causa, Aranzadi, Navarra, 2019, p. 92; I. ANTón JuÁrez, "Certificado Sucesorio Europeo", en A.-L. Calvo Caravaca/J. Carrascosa GonzÁlez (dirs.), Litigación Internacional en la Unión Europea (IV): Comentario al Reglamento (UE) núm. 650/2012 del Parlamento Europeo y del Consejo sobre sucesiones mortis causa, Aranzadi, Navarra, 2019, p. 335.

${ }^{159}$ Conclusiones del Abogado General Sr. M. Szpunar, presentadas el 13 de diciembre de 2017, Doris Margret Lisette Mahnkopf, C-558/16, ECLI:EU:C:2017:965, apartado 26; Conclusiones del Abogado General Sr. M. Szpunar, presentadas el 22 de febrero de 2018, Vincent Pierre Oberle, C-20/17, ECLI:EU:C:2018:89, apartado 101. Vid. M. SzPunAr, "Droit international privé de l'Union: cohérence des champs d'application et/ou des solutions?", Revue Critique Droit International Privé, juilletseptembre 2018, p. 578.

${ }^{160}$ Conclusiones del Abogado General Sr. M. Szpunar, presentadas el 22 de febrero de 2018, Vincent Pierre Oberle, C-20/17, ECLI:EU:C:2018:89, apartado 105.

${ }^{161}$ Ibidem, apartado 106.

${ }^{162}$ Idem, apartado 108.

${ }^{163}$ STJUE 12 octubre 2017, Kubicka, C-218/16, EU:C:2017:755, apartado 57.

${ }^{164}$ Conclusiones del Abogado General Sr. M. Szpunar, presentadas el 22 de febrero de 2018, Vincent Pierre Oberle, C-20/17, ECLI:EU:C:2018:89, apartado 109. 
650/2012, sino que estaba en vigor el $9.8 \mathrm{CC}^{165}$. Así el principio de unidad y universalidad de la sucesión del Derecho internacional privado español regía la ley aplicable a sucesión, de manera que debía aplicarse una única ley con independencia del lugar de situación de los bienes hereditarios y la naturaleza de los mismos ${ }^{166}$. Pues bien, con la entrada en vigor del Reglamento (UE) 650/2012 también se persigue la unidad de la sucesión en cuanto a la ley aplicable. Sin embargo, por lo que respecta de competencia internacional en materia de sucesiones es muy difícil que no haya fraccionamiento de la sucesión, cuando precisamente los foros de competencia previstos no contribuyen al mismo.

65. En tercer lugar, en opinión del Abogado General, el interés de las personas por la tramitación rápida, ágil y eficiente de las sucesiones puede suponer un argumento en favor de aquellos instrumentos que les permitan tramitar las sucesiones en otro Estado miembro distinto del Estado miembro cuyas autoridades son competentes en virtud de las normas del Reglamento (UE) 650/2012 167 . En su opinión, se puede reconocer como uno de los fines del Reglamento (UE) 650/2012, pero no hay que olvidarse tampoco de la importancia del buen funcionamiento de la justicia ${ }^{168}$.

En este mismo sentido, el Abogado General señala que en el marco del Reglamento (UE) 650/2012, no solo en interés de los causahabientes, sino también en aras del interés del buen funcionamiento de la justicia, se deben evitar situaciones en las que pueden existir instrumentos de tramitación de las sucesiones incompatibles entre si ${ }^{169}$. También se debe tener en cuenta la voluntad de garantizar la coincidencia del ius y del foro especialmente perseguidos por el Reglamento (UE) 650/2012 $2^{170}$.

66. Por lo tanto, el Abogado General no considera que los fines del Reglamento (UE) 650/2012 permitan que se interpreten sus disposiciones de forma opuesta a las conclusiones de la interpretación sistemática, para que los interesados consigan que los certificados sucesorios nacionales se expiden por los tribunales de un Estado miembro que no sea el Estado cuyas autoridades son competentes en virtud del art. 4 del Reglamento sucesorio ${ }^{171}$. Sin embargo, en mi opinión con esta conclusión se está incumpliendo con otro principio que rige el Reglamento sucesorio, que es el de subsidiariedad del certificado sucesorio europeo frente a los documentos que pueden existir con efectos similares en los Estados miembros ${ }^{172}$.

Para el Abogado General esta interpretación limitaría la posibilidad de expedir en diferentes Estados miembros certificados sucesorios nacionales y otros instrumentos, incluidos los certificados sucesorios europeos, resoluciones y documentos públicos incompatibles entre sí1 ${ }^{173}$.

\section{c) Interpretación histórica del Abogado General en las Conclusiones de la sentencia}

67. Es cierto, que tal y como señala el Abogado General, las conclusiones que se han obtenido hasta ahora a partir de la interpretación sistemática y teleológica, -a las que he ido haciendo algunas observaciones-, son ratificadas por la interpretación histórica del Reglamento (UE) 650/2012 ${ }^{174}$.

${ }^{165}$ E. Castellanos Ruiz, "Sucesión Hereditaria. El Reglamento Sucesorio Europeo”, en A.-L. Calvo Caravaca/J. Carrascosa GonzÁlez (dirs.), Derecho Internacional Privado, Volumen II, Comares, Granada, 2013, pp. 534.

${ }^{166}$ Así no se aceptaba el reenvío de primer grado que llevaba a la ley española, previsto en el art. 12.2 CC, si dicho reenvío provocaba un fraccionamiento de la sucesión (E. CAStellanos Ruiz, "Sucesión Hereditaria. El Reglamento Sucesorio Europeo", en A.-L. Calvo Caravaca/J. Carrascosa González (dirs.), Derecho Internacional Privado, Volumen II, Comares, Granada, 2013, pp. 534).

${ }^{167}$ Conclusiones del Abogado General Sr. M. Szpunar, presentadas el 22 de febrero de 2018, Vincent Pierre Oberle, C-20/17, ECLI:EU:C:2018:89, apartado 102.

${ }^{168}$ Ibidem, apartado 111.

${ }^{169}$ Idem, apartado 112.

170 Vid. M. SzPunAR, “Droit international privé de l'Union: cohérence des champs d'application et/ou des solutions?”, Revue Critique Droit International Privé, juillet-septembre 2018, p. 578.

${ }^{171}$ Conclusiones del Abogado General Sr. M. Szpunar, presentadas el 22 de febrero de 2018, Vincent Pierre Oberle, C-20/17, ECLI:EU:C:2018:89, apartado 114.

${ }^{172}$ Considerando (69) Reglamento (UE) 650/2012.

173 Ibidem, apartado 110.

${ }^{174}$ Idem, apartado 115. 
La Propuesta de Reglamento sucesorio de la Comisión ya establecía que el certificado sucesorio europeo "no sustituirá a los procedimientos internos", de su art. 36.2 ${ }^{175}$. Sin embargo, en el apartado 4.6 de la exposición de motivos de la Propuesta se dejó todavía más claro que el certificado europeo "no sustituye a los certificados ya existentes en algunos Estados miembros". Así que finalmente en el art. 62.3 del Reglamento sucesorio -art. 36.2 de la Propuesta de Reglamento- quedó reflejada esta propuesta en "el certificado no sustituirá a los documentos internos empleados en los Estados miembros para fines similares".

Por su parte, también el apartado 4.6 de la exposición de motivos de la Propuesta de Reglamento señaló expresamente "en el Estado miembro de la autoridad competente, la prueba de la cualidad de heredero y de los poderes del administrador o ejecutor de la sucesión se efectúa, por tanto, conforme al procedimiento interno".

Así que en opinión del Sr. M. Szpunar, en la Propuesta de Reglamento ya se redujo el papel de la normativa procesal nacional a materias relacionadas con el curso del procedimiento, que tal y como propone debería iniciarse "en el Estado miembro de la autoridad competente", no considerando que dicha competencia tenga que ser otorgada con arreglo a la ley nacional ${ }^{176}$.

En opinión del Abogado General se puede afirmar que incluso en la redacción de la Propuesta del Reglamento sucesorio, ya se podía prever que la ley nacional no iba a decidir la competencia internacional de las autoridades de los Estados miembros en relación a la expedición de los certificados sucesorios nacionales, sino que iban a ser de aplicación las normas de competencia establecidas en el Reglamento ${ }^{177}$.

En definitiva, el art. 4 del Reglamento (UE) 650/2012 debe interpretarse en el sentido de que determina la competencia también en relación con los procedimientos en los que conocen los tribunales de los Estados miembros para la expedición de los certificados sucesorios nacionales ${ }^{178}$.

\section{d) Conclusiones}

68. Así pues, se procede a responder a la cuestión prejudicial, teniendo en cuenta que la interpretación literal no ofrece ninguna solución clara, pero que las interpretaciones sistemática y teleológica son unívocas y están apoyadas por la interpretación histórica. El Abogado General considera que el art. 4 del Reglamento (UE) 650/2012 atribuye la competencia con respecto a aquellos procedimientos en los que conocen los tribunales de los Estados miembros cuando dichos procedimientos se refieran a materias que pertenecen a "la totalidad de la sucesión"; siendo este el caso de los certificados sucesorios nacionales ${ }^{179}$.

Se va a resumer brevemente los argumentos del fallo de la sentencia del TJUE que hace suyos los argumentos del Abogado General M. Szpunar, para finalizar este estudio con cuáles son las implicaciones de dicho resultado para los Estados miembros ${ }^{180}$.

69. En el apartado 33, se señala en primer lugar, que las reglas para determinar la competencia, en la medida en que no remitan al Derecho de los Estados miembros para esclarecer su sentido y alcance, deben ser objeto de una interpretación autónoma y uniforme. Esta debe realizarse teniendo en cuenta no solo el tenor literal de las propias disposiciones, sino también su contexto y los objetivos perseguidos por la normativa de la que formen parte, en este caso el Reglamento de sucesiones ${ }^{181}$.

175 Propuesta de reglamento del Parlamento Europeo y del Consejo relativo a la competencia, la ley aplicable, el reconocimiento y la ejecución de las resoluciones y los actos auténticos en materia de sucesiones y a la creación de un certifcado sucesorio (COM/2009/0154 final - COD 2009/0157).

${ }^{176}$ Conclusiones del Abogado General Sr. M. Szpunar, presentadas el 22 de febrero de 2018, Vincent Pierre Oberle, C-20/17, ECLI:EU:C:2018:89, apartados 114-117.

177 Ibidem, apartado 118.

178 Idem, apartado 120.

${ }^{179}$ Idem, apartado 119.

${ }^{180}$ STJUE 21 junio 2018, Vincent Pierre Oberle, C-20/17, ECLI:EU:C:2018:485.

${ }^{181}$ STJUE 1 marzo 2018, Mahnkopf, C-558/16, ECLI:EU:C:2018:138, apartado 32. 
En segundo lugar, según la redacción del propio art. 4, los tribunales del Estado miembro en el que el causante tuviera su residencia habitual en el momento del fallecimiento tendrán competencia para pronunciarse sobre la totalidad de la sucesión, luego la regla de competencia se refiere a la "totalidad de la sucesión"182.

70. Por otro lado, el tenor literal del art. 4 no permite establecer si la naturaleza contenciosa o de jurisdicción voluntaria del procedimiento afecta a la aplicabilidad de la regla para determinar la competencia, ni si por "resolver" ha de entenderse el hecho de adoptar una resolución de naturaleza jurisdiccional. Por lo tanto, la interpretación literal del artículo 4 no responde a la cuestión de si un procedimiento de expedición de los certificados sucesorios nacionales debe considerarse comprendido en el ámbito de aplicación del art. $4^{183}$.

En cuanto al análisis del contexto en el que se circunscribe el art. 4, el art. 13 señala que además del tribunal competente para resolver la sucesión de conformidad con el Reglamento, los tribunales del Estado miembro de la residencia habitual de cualquier persona que, con arreglo a la ley aplicable a la sucesión, pueda efectuar una declaración relativa a la aceptación de la herencia, de un legado o de la parte legítima o la renuncia a los mismos, o una declaración de limitación de su responsabilidad respecto de las deudas y demás cargas de la herencia, serán competentes para conocer de esas declaraciones ${ }^{184}$.

El art. 13 pretende simplificar los trámites de los herederos y de los legatarios, estableciendo excepciones a las reglas para determinar la competencia (arts. 4 a 11). Sin embargo, los tribunales competentes para resolver sobre la totalidad de una sucesión en virtud del artículo 4 del citado Reglamento son competentes para conocer sobre las declaraciones sucesorias, es decir, sobre procedimientos que no concluyen con la adopción de una resolución judicial ${ }^{185}$.

En consecuencia, el art. 4 determina la competencia internacional de los tribunales de los Estados miembros relativa a los procedimientos sobre medidas acerca de la "totalidad de una sucesión", tales como, la expedición de los certificados sucesorios nacionales, con independencia de la naturaleza contenciosa o de jurisdicción voluntaria de esos procedimientos ${ }^{186}$.

Esta interpretación no es contradictoria con lo señalado por el art. 64 puesto que tiene por objeto precisar que tanto los tribunales como algunas otras autoridades serán competentes para expedir el certificado sucesorio europeo; al mismo tiempo que especifica que la determinación de la competencia para la expedición de tales certificados tendrá que hacerse de acuerdo con los arts. 4, 7, 10 y 11 del propio Reglamento ${ }^{187}$.

71. Por último, se señala en dicha sentencia que uno de los objetivos del Reglamento es la unidad de la sucesión; así como ayudar a los herederos y legatarios, a las personas próximas al causante y a los acreedores de la herencia a ejercer sus derechos en situaciones de sucesión mortis causa con repercusiones transfronterizas; y permitir a los ciudadanos de la Unión preparar su sucesión. Por ello es necesario establecer un régimen uniforme aplicable a las sucesiones mortis causa con repercusiones transfronterizas, reduciendo el riesgo de que se sustancien procedimientos paralelos ante los tribunales de los distintos Estados miembros y de que surjan resoluciones contradictorias ${ }^{188}$.

Así que se obstaculizaría la consecución de los fines del Reglamento sucesorio, si en una situación como la del litigio principal, las disposiciones del capítulo II tuvieran que interpretarse de manera que no determinan la competencia internacional de los tribunales de los Estados miembros en materia de los procedimientos relativos a la expedición de los certificados sucesorios nacionales ${ }^{189}$.

72. Así pues, el art. 4 debe interpretarse de forma que se opone a una normativa de un Estado miembro, que señala que, aunque el causante no tuviera en el momento del fallecimiento su residencia

\footnotetext{
${ }^{182}$ STJUE 21 junio 2018, Vincent Pierre Oberle, C-20/17, ECLI:EU:C:2018:485, apartados 34 y 37.

183 Ibidem, apartados 38-40.

${ }^{184}$ Idem, apartado 41.

${ }^{185}$ Idem, apartado 42.

${ }^{186}$ Idem, apartado 44

${ }^{187}$ Idem, apartados 45-46.

${ }^{188}$ Idem, apartados 49-57.

${ }^{189}$ Idem, apartado 58.
} 
habitual en ese Estado miembro, los tribunales de dicho Estado miembro seguirán siendo competentes para expedir los certificados sucesorios nacionales, de conformidad con los criterios de sus normas de producción interna, que no son otros que la existencia de bienes hereditarios situados en dicho Estado miembro o que el causante hubiera sido nacional del mismo ${ }^{190}$.

Por lo tanto, como ya se ha mencionado, con esta conclusión, se está favoreciendo que los interesados soliciten certificados sucesorios europeos. Si el causahabiente tiene que acudir al tribunal competente por el foro recogido en el art. 4 del Reglamento sucesorio y no coincide con el lugar de su residencia habitual, dado que tiene que soportar costes conflictuales, preferirá solicitar un certificado sucesorio europeo; pues contempla los mismos foros de competencia internacional ${ }^{191}$.

73. En conclusión, para la determinación de la competencia en materia de expedición de los certificados sucesorios nacionales y los procedimientos relativos a los mismos, se debe distinguir qué autoridad, judicial o no judicial, realiza el certificado sucesorio en el Estado miembro en cuestión:

$\left.1^{\circ}\right)$ Si quienes emiten el certificado sucesorio nacional son órganos judiciales, estos deberán respetar las normas de competencia internacional del Reglamento (UE) 650/2012. Para el fallo de la sentencia Vincent Pierre Oberle, ha sido fundamental la consideración de que en el supuesto concreto, se trataba de órganos judiciales, en el ejercicio de sus funciones jurisdiccionales, porque si no se hubiese entendido así, el fallo hubiese sido totalamente diferente ${ }^{192}$. Tal y como se ha podido comprobar posteriormente con el fallo de la sentencia sobre el asunto WB c Notariusz Przemystawa Bac ${ }^{193}$.

Así, en el asunto Vincent Pierre Oberle, se trataba de un caso en que el finado no había optado por una professio juris. Pero si la hubiera realizado, hubieran sido competentes para la expedición del certificado sucesorio nacional, los tribunales del Estado miembro de la nacionalidad del causante. Por las mismas razones, el foro de necesidad, en virtud del art. 11 del Reglamento sucesorio, podría igualmente otorgar competencia a los tribunales de un Estado miembro para los procedimientos relativos a la expedición de los certificados sucesorios nacionales, si se cumplen las condiciones restrictivas previstas en el Reglamento para su aplicación ${ }^{194}$.

$\left.2^{\circ}\right)$ Si quienes emiten el certificado sucesorio nacional son autoridades no judiciales que no ejercen funciones jurisdiccionales, no pueden ser considerados "tribunal" a los efectos del Reglamento sucesorio, por lo que no tendrán que respetar las normas de competencia internacional del Reglamento (UE) 650/2012. Precisamente esto es lo que se resuelve en el asunto WB c Notariusz Przemystawa $B a c^{195}$. En ese caso, serán de aplicación las normas de producción interna para la determinación de la competencia en relación con la expedición de los certificados sucesorios nacionales y los procedimientos relativos a los mismos.

$3^{\circ}$ ) Por último, si quienes expiden el certificado sucesorio nacional son autoridades no judiciales que ejercen funciones jurisdiccionales, deberán respetar las normas de competencia internacional, porque serán considerados "tribunal", de conformidad con el art. 3.2 del Reglamento sucesorio. Aunque no existe sentencia del TJUE al respecto que lo establezca, esta última aseveración puede deducirse de los dos casos anteriores.

\footnotetext{
${ }^{190}$ Idem, apartado 59.

191 Vid. en este sentido, M.-J. Castellanos Ruiz, "Competencia internacional”, en A.-L. Calvo Caravaca/J. Carrascosa GonZÁlez (dirs.), Litigación Internacional en la Unión Europea (IV): Comentario al Reglamento (UE) núm. 650/2012 del Parlamento Europeo y del Consejo sobre sucesiones mortis causa, Aranzadi, Navarra, 2019, p. 92; I. ANTÓN JuÁrEz, "Certificado Sucesorio Europeo", en A.-L. Calvo Caravaca/J. Carrascosa GonzÁlez (dirs.), Litigación Internacional en la Unión Europea (IV): Comentario al Reglamento (UE) núm. 650/2012 del Parlamento Europeo y del Consejo sobre sucesiones mortis causa, Aranzadi, Navarra, 2019, p. 335.

192 STJUE 21 junio 2018, Vincent Pierre Oberle, C-20/17, ECLI:EU:C:2018:485, apartado 60.

${ }_{193}$ STJUE 23 mayo 2019, WB c Notariusz Przemystawa Bac, C-658/17, ECLI:EU:C:2019:444, apartado 73.

${ }^{194}$ L. Perreau-Saussine, "Quelle place pour les certificats successoraux nationaux dans le règlement européen Successions internationales, no 650/2012?", Revue Critique Droit International Privé, octobre-décembre 2018, p. 859.

195 STJUE 23 mayo 2019, WB c Notariusz Przemystawa Bac, C-658/17, ECLI:EU:C:2019:444, apartado 73.
} 


\section{Implicaciones para los Estados miembros}

74. $\left.1^{a}\right)$ Normas de competencia para la expedición del certificado sucesorio nacional. En primer lugar, si es un órgano judicial de un Estado miembro el que realiza el certificado sucesorio nacional, será competente en lo relativo a la expedición de tales certificados y los procedimientos relativos a ellos, el tribunal del Estado miembro designado por las normas de competencia internacional del capítulo II del Reglamento (UE) 650/2012.

En mi opinión, para el TJUE es más difícil dictaminar que cuando son los órganos judiciales los que emiten los certificados sucesorios nacionales, no están ejerciendo "funciones jurisdiccionales"; así que para que decidan que no las ejercen, las circunstancias del caso deben ser determinantes y que no existan dudas al respecto; algo que sí sucedía en el asunto Vincent Pierre Oberle. Además, el TJUE será más proclive que en el caso de planaterse asuntos similares, en los que quien expide el certificado sucesorio nacional es un órgano judicial, éste tenga que respetar obligatoriamente las normas de competencia del Reglamento (UE) 650/2012. Me estoy refiriendo a que, por cuestiones de economía procesal, si es un órgano judicial el que realiza el certificado sucesorio nacional, dicho órgano judicial estará obligado a cumplir las normas de competencia internacional, sin tener que entrar a analizar los aspectos del caso concreto. Este efectivamente ha sido el fallo de la sentencia del Vincent Pierre Oberle, aunque no en base a estos argumentos, sino tras el análisis por parte del TJUE de las interpretaciones realizadas por el Abogado General, el Sr. M. Szpunar.

Se debe destacar que, para la Comisión son los Estados miembros los que deben decidir de forma autónoma quiénes tienen que expedir los certificados sucesorios nacionales. Eso sí, el Estado miembro debe aceptar los efectos que produce esta elección cuando elige a los órganos jurisdiccionales para que desempeñen esta función, como sucede en Alemania. En ese caso, el certificado sucesorio nacional expedido por un órgano jurisdiccional constituye -como también lo señala el Gobierno polaco- una "resolución" en el sentido del art. 3.1.g) del Reglamento (UE) 650/2012, con independencia de la posición que haya adoptado el Derecho nacional en esta materia.

El Abogado General concluye que el art. 4 atribuye la competencia respecto de los procedimientos planteados ante los órganos jurisdiccionales de los Estados miembros cuando estos procedimientos se refieren a materias que pueden considerarse que entran dentro de "la totalidad de la sucesión", con independencia de que este procedimiento sea o no contencioso.

75. En segundo lugar, si quienes emiten los certificados sucesorios nacionales son "las demás autoridades y profesionales del Derecho" en el sentido del art. 3.2 del Reglamento (UE) 650/2012, la solución es diferente, porque para que puedan ser consideradas "tribunales" es necesario que cumplan obligatoriamente funciones jurisdiccionales. Así sucedió en el asunto WB c. Notariusz Przemystawa Bac que ha sido mencionado, en el que tras un análisis del concepto "funciones jurisdiccionales" y de su aplicación al caso concreto, se determinó que los notarios polacos, que tenían que redactar un documento a solicitud de todas las partes del procedimiento notarial, no ejercían funciones jurisdiccionales ${ }^{196}$.

Como se trata de autoridades no judiciales, que desempeñan distintas funciones en un mismo Estado miembro y a su vez entre Estados miembros, el TJUE considera que se debe analizar si la autoridad no judicial cumple funciones jurisdiccionales en un Estado miembro, para el asunto en cuestión. Un ejemplo de esto es la sentencia del TJUE en el asunto WB c. Notariusz Przemysława Bac ${ }^{197}$. Lo cual es lógico, porque las autoridades no judiciales, no siempre cumplen funciones jurisdiccionales en el sentido del Reglamento (UE) 650/2012.

Pero si en el asunto WB c. Notariusz Przemystawa Bac, el TJUE hubiese considerado que los notarios polacos ejercían funciones jurisdiccionales, en el sentido del art. 3.2 del Reglamento (UE) 650/2012, hubieran sido de aplicación las normas de competencia internacional del capítulo II del Reglamento sucesorio; siguiendo la misma línea interpretativa realizada por el TJUE en el asunto Vincent Pierre Oberle.

${ }^{196}$ Conclusiones del Abogado General Sr. Y. Bot, presentadas el 28 de febrero de 2019, WB c. Notariusz Przemystawa Bac, C-658/17, ECLI:EU:C:2019:166, apartados 81-98.

${ }^{197}$ STJUE 23 mayo 2019, WB c Notariusz Przemysława Bac, C-658/17, ECLI:EU:C:2019:444, apartado 73. 
76. $2^{a}$ ) Comunicaciones de los Estados miembros a la Comisión, de conformidad con los arts. 78.1.c) y 79.1. En definitiva, las normas de competencia internacional del Reglamento (UE) 650/2012 determina la competencia también en relación con los procedimientos en los que conocen los tribunales de los Estados miembros para la expedición de los certificados sucesorios nacionales ${ }^{198}$. El fallo de la sentencia en el asunto Vincent Pierre Oberle tiene repercusiones en aquellos Estados miembros en los que existe la posibilidad de que los órganos jurisidiccionales expidan certificados sucesorios nacionales, como ocurre con Alemania y España.

Como se ha dicho en reiteradas ocasiones, también es posible que sean considerados "tribunal" no sólo los órganos judiciales, sino otras autoridades no judiciales como los notarios, porque ejercen funciones jurisdiccionales en un Estado miembro, en el sentido del art. 3.2 del Reglamento (UE) 650/2012. Así que los Estados miembros notificarán a la Comisión, las autoridades y los profesionales del Derecho que se consideran "tribunales" en el sentido del Reglamento sucesorio, de conformidad con el art. 79.1.

Así pues, Francia ha señalado que los notarios no ejercen funciones jurisdiccionales, y que no son un "tribunal" en el sentido del Reglamento ${ }^{199}$. Por lo tanto, no ha hecho ninguna comunicación al respecto, de conformidad con el art. 79.1 del Reglamento (UE) 650/2012, indicando que los notarios deben ser considerados "tribunales" en el sentido del art. 3.2 del Reglamento (UE) 650/2012. Sin embargo, Francia ha señalado, que los notarios son las autoridades competentes para la expedición de los certificados sucesorios europeos, con lo que deberán respetar las normas de competencia previstas en el art. 64 del Reglamento sucesorio ${ }^{200}$.

En esta misma línea, ni Alemania, ni Bélgica han realizado ninguna notificación de conformidad con el art. 79.1 del Reglamento (UE) 650/2012, indicando que los notarios deben ser considerados "tribunales" a efectos del art. 3.2 del Reglamento (UE) 650/2012 ${ }^{201}$. Por lo tanto, ni los notarios alemanes, ni los belgas, tienen que respetar las normas de competencia internacional en materia de expedición de los certificados sucesorios nacionales. No obstante, de acuerdo con el art. 78.1.c), ambos países sí que han notificado a la Comisión que los notarios son "otra autoridad" a efectos de la expedición del certificado en virtud del artículo 64 del Reglamento (UE) 650/2012. Por ejemplo, Bélgica ha señalado de forma literal que "Las autoridades competentes a efectos de la expedición del certificado en virtud del artículo 64 son los notarios" 202 .

En consecuencia, a diferencia de España, ninguno de los Estados miembros mencionados ha señalado que los notarios deban ser considerados "tribunal" en el sentido del art. 3.2 del Reglamento sucesorio, por lo tanto, no están sujetos a las normas de competencia judicial internacional, como es el caso del art. 4 de dicho instrumento internacional. Es más no han hecho niguna notificación con respecto a qué otras autoridades o profesionales del Derecho deben ser considerados "tribunal", además de los órganos judiciales; así que en dichos Estados miembros únicamente los órganos judiciales están sujetos a las normas de competencia judicial internacional del capítulo II del Reglamento sucesorio.

198 Idem, apartado 59.

199 H. GAudemet-TALlon, "Les RĖGLES DE COMPÈTENCE JUDICIARIE DANS LE RÈGLEMENT EUROPÉEN SUR LES SUCCESSIONS", EN AA.VV. (sous la DiRECTION DE G. Khairallah/M. ReVILlard), Droit européen des successions internationales (Le Règlement du 4 juillet 2012), Defrénois, Paris, 2013, p. 129; L. Perreau-Saussine, “Quelle place pour les certificats successoraux nationaux dans le règlement européen Successions internationales, no 650/2012?”, Revue Critique Droit International Privé, octobredécembre 2018, p. 858.

200 La comunicación con respecto a las autoridades que son competentes para emitir el certificado sucesorio europeo, así como otras notificaciones previstas en el Reglamento (UE) 650/2012, de conformidad con los arts. 78 y 79 , que Francia ha realizado, están disponibles en línea en https://e-justice.europa.eu/content_succession-380-fr-es.do?member=1 (consultada el 10 de diciembre de 2019).

${ }^{201}$ La comunicación indicando que los notarios deben ser considerados "tribunal" en el sentido del art. 3.2 del Reglamento (UE) 650/2012; o la notificación señalando si los notarios son “otra autoridad” en el sentido del art. 64 del Reglamento sucesorio, y que por tanto, son competentes para emitir el certificado sucesorio europeo, además de los tribunales; así como otras notificaciones previstas en el Reglamento (UE) 650/2012, de conformidad con los arts. 78 y 79; están disponibles en línea para Alemania en https://e-justice.europa.eu/content_succession-380-de-es.do?member=1; y para Bélgica en https://e-justice.europa.eu/content_succession-380-be-es.do?member=1 (consultadas el 10 de diciembre de 2019).

${ }^{202}$ Las notificaciones de Bélgica, de conformidad con los arts. 78 y 79 del Reglamento (UE) 650/2012, están disponibles en línea en https://e-justice.europa.eu/content_succession-380-be-es.do?member=1 (consultada el 10 de diciembre de 2019). 
77. En el caso de España la situación en relación con los notarios es diferente porque España ha hecho las dos declaraciones, de conformidad con los arts. 78.1.c) y 79.1 del Reglamento (UE) 650/2012.

Así España ha comunicado a la Comisión que los "notarios" son "otras autoridades" en el sentido del art. 3.2 del Reglamento (UE) 650/2012 y que, por tanto, ejercen "funciones jurisdiccionales" 203 . España ha señalado que, en relación a determinados actos de jurisdicción voluntaria, los notarios ejercen funciones jurisdiccionales, concretamente ha notificado que son considerados "tribunal": "los notarios, en relación a las declaraciones de herederos abintestato, a los procedimientos de presentación, adveración, apertura y protocolización de los testamentos cerrados, ológrafos y orales y a la formación de inventario" 204 . Y a continuación indica los notarios territorialmente competentes en España para realizar estos actos de jurisdicción voluntaria: “Arts. 55 y 56; 57 a 65 y 67 a 68 de la Ley del Notariado, en redacción dada por la Disposición Final $11^{a}$ de la Ley 15/2015, de 2 de julio, de la Jurisdicción Voluntaria"205.

En consecuencia, para estos actos de jurisdicción voluntaria, entre los que no se han incluído las actuaciones relativas a los contadores partidores o la aprobación de la partición-que también son actos de jurisdicción voluntaria- los notarios están sometidos a las normas de competencia internacional. De manera que, si no se cumple ningún foro de competencia internacional de los señalados en el capítulo II del Reglamento (UE) 650/2012 que atribuya competencia a un "tribunal", ningún notario español podrá realizar ninguno de los actos de jurisdicción voluntaria antes indicados. Una vez que exista un foro de competencia internacional, será territorialmente competente el notario establecido por la Ley del Notariado, en virtud de los preceptos arriba señalados.

Ahora bien, el problema se plantea porque en relación con los certificados sucesorios europeos, España ha comunicado a la Comisión de forma literal que dicho certificado "Se expedirá por órgano judicial o notario competente en cada caso", de conformidad con los arts. 78.1.c) del Reglamento (UE) $650 / 2012^{206}$. Dado que España ya había realizado la anterior comunicación señalando que los notarios deben ser considerados "tribunales", en el sentido del art. 3.2 del Reglamento (UE) 650/2012, para los actos de jurisdicción voluntaria indicados; los notarios ya eran autoridad competente para expedir los certificados sucesorios europeos que derivan de dichos expedientes. Efectivamente el art. 64 del Reglamento (UE) 650/2012 señala que son autoridad competente para emitirlos tanto "los tribunales" según se define en el art. 3.2; como "otra autoridad" que, en virtud del Derecho nacional, sea competentes para sustanciar sucesiones mortis causa. Por lo que, además, con esta segunda notificación, los notarios españoles son "otra autoridad" para expedir certificados sucesorios europeos derivados de otros actos.

Así que cuando se trate de realizar un certificado sucesorio europeo que derive de un expediente de jurisdicción voluntaria relativo a cualquiera de los actos notificados a la Comisión, de conformidad con el art. 79.1, y por tanto ser considerado "tribunal", el notario español no podrá declararse competente -en virtud de la Ley del Notariado-, si no cumple previamente con algún foro de competencia internacional del Reglamento (UE) 650/2012. Pero en relación con el resto de actos no notificados a la Comisión, como son las actuaciones relativas a los contadores partidores o la aprobación de la partición, el notario español no tendrá que respetar las normas de competencia internacional del Reglamento (UE) 650/2012; y podrá hacerlo para dichos actos en virtud del art. 66 de la Ley del Notariado ${ }^{207}$. En la comunicación de España a la Comisión no se incluyeron las actuaciones sobre albaceas o contadores, ni tampoco la aprobación de la partición, porque sólo notificó los expedientes sucesorios en los que

${ }^{203}$ E. Castellanos Ruiz, "Sucesión Hereditaria. El Reglamento Sucesorio Europeo", en A.-L. Calvo Caravaca/J. CarrasCosa GonZÁlez (dirs.), Derecho Internacional Privado, Volumen II, Comares, Granada, 2018, p. 686.

${ }^{204}$ Las notificaciones de España, de conformidad con los arts. 78 y 79 del Reglamento (UE) 650/2012, están disponibles en línea en https://e-justice.europa.eu/content_succession-380-es-es.do?member=1 (consultada el 10 de diciembre de 2019).

${ }^{205}$ Las notificaciones de España, de conformidad con los arts. 78 y 79 del Reglamento (UE) 650/2012, están disponibles en línea en https://e-justice.europa.eu/content_succession-380-es-es.do?member=1 (consultada el 10 de diciembre de 2019).

${ }^{206}$ Las notificaciones de España, de conformidad con los arts. 78 y 79 del Reglamento (UE) 650/2012, están disponibles en línea en https://e-justice.europa.eu/content_succession-380-es-es.do?member=1 (consultada el 10 de diciembre de 2019).

${ }^{207}$ Art. 66 Ley del Notariado de 1862, Gaceta de Madrid núm. 149, de 29 mayo 1862, modificado por la Disposición Final undécima de la Ley 15/2015 de la Jurisdicción Voluntaria (BOE núm. 158, de 3 julio 2015: "Será competente el Notario que tenga su residencia en el lugar en que hubiera tenido el causante su último domicilio o residencia habitual, o donde estuviere la mayor parte de su patrimonio, con independencia de su naturaleza de conformidad con la ley aplicable, o en el lugar en que hubiera fallecido, siempre que estuvieran en España, a elección del solicitante. También podrá elegir a un Notario de un distrito colindante a los anteriores. En defecto de todos ellos, será competente el Notario del lugar del domicilio del requirente". 
los notarios poseen competencia exclusiva que sean actos de jurisdicción voluntaria ${ }^{208}$. Efectivamente, dichas actividades en los supuestos de los arts. 843 y 1057 CC se realizan de forma alternativa con los Secretarios judiciales (Letrados de la Administración de Justicia). Ahora bien, si las actuaciones sobre los albaceas o contadores y la aprobación de la partición son llevadas a cabo por los Secretarios judiciales, como actúan por mandato judicial, están sometidas a las reglas de competencia judicial internacional, como los jueces ${ }^{209}$.

En cualquier caso, esta disparidad de criterios para la atribución de la competencia a los notarios según qué actos, se produce si se sigue la línea interpretativa del art. 64 del Reglamento sucesorio, realizada por R. CRÔNE y P. WAUTELET, y que se analiza en el tercer apartado ${ }^{210}$.

78. En cuanto a la notificación o comunicación que deberán hacer los Estados miembros en relación con el asunto $W B$ c Notariusz Przemystawa Bac, se señala al respecto que la falta de notificación a que se refiere el artículo 3.2 en su párrafo segundo, del Reglamento (UE) 650/2012, por parte de la República de Polonia, relativa al ejercicio por los notarios de funciones jurisdiccionales, no tiene carácter definitivo. Esto quiere decir que si los Estados no notifican que sus notarios son "otras autoridades" en el sentido del art. 3.2 Reglamento sucesorio, no implica que no puedan ser considerados "tribunal" y estar sometidos a las normas de competencia internacional del mismo.

El Abogado General Sr. Y. Bot señala que dicha calificación debe ser realizada por el órgano jurisdiccional nacional en cuestión, de forma autónoma, de manera que en cualquier caso la declaración realizada por la autoridad nacional competente no vincula a dicho órgano jurisdiccional; y eso se extrapolaría a los casos de ausencia de declaración ${ }^{211}$.

79. $3^{\circ}$ ) Normas de competencia para la expedición del certificado sucesorio europeo. Lo que expresa el art. 64 es que cualquiera de los Estados miembros designados por los arts. 4, 7, $10 \mathrm{u} 11$ es competente para expedir un certificado europeo. Así que parece que, según este precepto, para la determinación de la competencia en materia de expedición de los certificados europeos, se tendría que acudir a los mismos foros previstos que para otros litigios relativos a sucesiones.

Sin embargo, según la interpretación realizada por R. CRÔNE, en relación a los notarios franceses, como operan de modo extrajudicial, éstos pueden hacer valer su "competencia universal" 212 . Esta interpretación conduce a afirmar que los notarios pueden expedir el certificado sucesorio europeo si el Derecho nacional del Estado miembro al que pertenecen les otorga competencia internacional al efecto, sin que sea preciso que concurran los foros de competencia internacional recogidos en el Reglamento 650/2012 $2^{213}$.

En este mismo sentido, P. WAUTELET señala que, aunque los notarios no sean calificados como "tribunales", nada impide que sean considerados una autoridad que pueda emitir un certificado sucesorio europeo, puesto que según el art. 64, este puede ser emitido no sólo por un "tribunal" sino por "otra autoridad que, en virtud del Derecho nacional, sea competente para sustanciar sucesiones mortis causa"214. En opinión del legislador alemán, es el derecho nacional el que regula la competencia interna-

${ }^{208}$ A. Fernández-Tresgerres García, Las sucesiones mortis causa en Europa. Estudio del Reglamento $n^{\circ}$. 650/2012, Aranazadi, Pamplona, 2016, pp. 466-468.

209 A. Fernández-Tresgerres García, Las sucesiones mortis causa en Europa. Estudio del Reglamento $n^{\circ}$. 650/2012, Aranazadi, Pamplona, 2016, pp. 466-468.

${ }^{210} \mathrm{Si}$, por el contrario, se sigue la otra línea interpretativa, todas las autoridades señaladas por los Estados miembros para la expedición de los certificados sucesorio europeos, que en virtud del Derechio nacional sean competentes para sustanciar las sucesiones mortis causa, como son los notarios, deberán respetar las normas de competencia internacional del Reglamento (UE) 650/2012 y no podrán declararse competentes por sus normas de producción interna para la expedición de tales certificados.

${ }^{211}$ STJUE 23 mayo 2019, WB c Notariusz Przemystawa Bac, C-658/17, ECLI:EU:C:2019:444, apartados 40-49; Conclusiones del Abogado General Sr. Y. Bot, presentadas el 28 de febrero de 2019, WB c. Notariusz Przemystawa Bac, C-658/17, ECLI:EU:C:2019:166, apartados 64-69.

${ }^{212}$ R. CRÔne, "Le certificat succesoral européen”, en AA.VV. (sous la direction de G. Khairallah/M. Revillard), Droit européen des successions internationales (Le Règlement du 4 juillet 2012), Defrénois, Paris, 2013, pp. 178-179.

${ }^{213}$ J. CARrascosa GonzÁlez, "Reglamento sucesorio europeo y actividad notarial", Cuadernos de Derecho Transnacional, vol. 6, n ${ }^{\mathrm{o}}$ 1, marzo 2014, p. 42.

${ }^{214}$ P. Wautelet, “Article 3: Definitions” en A. Bonomi/P. Wautelet/I. Pretelli/A. ÖztürK, Le droit européen des successions. Commentaire du Règlement no 650/2012 du 4 juillet 2012, 2a ed., Bruylant, Bruxelles, 2016, pp. 178-179. 
cional para la expedición del certificado sucesorio europeo, independientemente de los art. 4 y siguientes del Reglamento, relativos a la competencia internacional ${ }^{215}$.

En mi opinión, de la afirmación realizada en el apartado 22 por el Abogado General en sus Conclusiones en el asunto Vincent Pierre Oberle, podría deducirse que: cuando los Estados miembros comuniquen a la Comisión que los notarios son "otra autoridad" para emitir los certificados sucesorios europeos, estos no tienen que respetar las normas de competencia internacional, sino que su competencia deriva del derecho nacional del Estado miembro en cuestión. Esta es la opción más acertada y que se adapta mejor a los fines del Reglamento.

En opinión de J. CARRASCOSA GonzÁlez, la victoria notarial es clara, puesto que mientras los tribunales están "limitados" por los foros recogidos en el Reglamento para expedir el certificado sucesorio europeo, los notarios no lo están, por lo que podrán expedir el certificado sucesorio europeo en un mayor número de casos que los tribunales.

80. En cualquier caso, la sentencia del asunto Vincent Pierre Oberle no resuelve la cuestión anterior de forma clara. Tampoco aborda la problemática en relación a si los foros de competencia del art. 64 son alternativos o jerárquicos; que será objeto con toda seguridad de una futura cuestión prejudicial.

81. $4^{\circ}$ ) Obligatoriedad del certificado sucesorio europeo. Una de las conclusiones más importantes ya adelantadas del fallo de la Sentencia en el asunto Vincent Pierre Oberle es que, en mi opinión, aunque efectivamente al igual que señala el Abogado General, el certificado sucesorio europeo no tiene carácter obligatorio, en virtud del art. 62.2 del Reglamento (UE) 650/2012, sí que va a llegar a serlo en la práctica.

Si para la expedición de los certificados sucesorios nacionales, se tienen que cumplir las normas de competencia internacional cuando en dicho Estado miembro es un tribunal el que los emite, no se está favoreciendo el que los Estados miembros soliciten la expedición de los certificados nacionales. Todo lo contrario, se está obligando a que por economía conflictual los interesados soliciten un certificado sucesorio europeo ante el tribunal competente, tanto para la expedición del certificado sucesorio europeo como del certificado nacional; en vez de tener que ir solicitando diferentes certificados nacionales en Estados con distintas normas sobre competencia internacional para la expedición de dichos certificados ${ }^{216}$. Por lo tanto, no se está obligando, en teoría, a los interesados a solicitar el certificado sucesorio europeo, pero sí que se está favoreciendo la utilización en mayor medida del certificado sucesorio europeo frente al certificado nacional.

Tampoco lleva a una postura diferente, según el Abogado General, el hecho de que los certificados sucesorios nacionales se destinen al tráfico interior en un Estado miembro determinado, tal y como se deduce de la interpretación del art. 62.3 del Reglamento (UE) 650/2012 ${ }^{217}$. En este sentido, el certificado sucesorio europeo "no sustituirá" a los certificados sucesorios nacionales, puesto que el certificado sucesorio europeo se expide para ser utilizado en otros Estados miembros que no sean el Estado cuyos órganos son competentes para expedir dicho certificado europeo (art. 62.1 del Reglamento (UE) $650 / 2012)^{218}$. Esto es así, siempre y cuando, las normas de competencia internacional no sean las mismas para la expedición de ambos tipos de certificados; porque si son las mismas, las personas van a preferir solicitar el certificado sucesorio europeo, para reducir los costes de trasladarse a cada uno de los Estados miembros que sean competentes para solicitar los correspondientes certificados nacionales.

${ }^{215}$ E. GeImer, "Die Ermittlung des gewöhnlichen Aufenthaltes des Erblassers durch das Nachlassgericht”, en R.A. SCHÜTZE (Hrsg.), Fairness Justice Equity: Festschrift für Reinhold Geimer zum 80. Geburtstag, München, Beck, 2017, pp. 117-118.

216 Vid. en este sentido, M.-J. Castellanos Ruiz, "Competencia internacional", en A.-L. Calvo Caravaca/J. Carrascosa GonZÁlez (dirs.), Litigación Internacional en la Unión Europea (IV): Comentario al Reglamento (UE) núm. 650/2012 del Parlamento Europeo y del Consejo sobre sucesiones mortis causa, Aranzadi, Navarra, 2019, p. 92; I. ANTón JuÁrez, "Certificado Sucesorio Europeo", en A.-L. Calvo Caravaca/J. Carrascosa GonzÁlez (dirs.), Litigación Internacional en la Unión Europea (IV): Comentario al Reglamento (UE) núm. 650/2012 del Parlamento Europeo y del Consejo sobre sucesiones mortis causa, Aranzadi, Navarra, 2019, p. 335.

${ }^{217}$ Conclusiones del Abogado General Sr. M. Szpunar, presentadas el 22 de febrero de 2018, Vincent Pierre Oberle, C-20/17, ECLI:EU:C:2018:89, apartado 38.

${ }^{218}$ Ibidem, apartado 38. 
En este sentido, precisamente una de las críticas que ha recibido el Reglamento de sucesiones con respecto al certificado sucesorio europeo es que tiene normas que se contradicen entre sí, de forma que no es fácil saber cual debe usarse preferentemente, si el certificado sucesorio europeo o el certificado nacional ${ }^{219}$. En el Reglamento se afirma que el certificado sucesorio europeo tiene carácter subsidiario con relación al certificado sucesorio nacional, y que no se va a favorecer al certificado sucesorio europeo; mientras que también se establece en otras disposiciones del Reglamento sucesorio que ambos certificados tienen carácter alternativo.

82. $^{\circ}$ ) Lege ferenda. De la redacción del Reglamento (UE) 650/2012 no se puede interpretar que los certificados sucesorios nacionales estén excluídos del ámbito de aplicación del mismo.

Sin embargo, sobre todo en lo que afecta a la coexistencia de ambos certificados sucesorios -el europeo y el nacional- debería haberse optado por cualquiera de estas posibilidades: a) la exclusión explícita de los certificados sucesorios nacionales, dejando a las normas de producción interna de cada uno de los Estados miembros su regulación; b) la inclusión dentro del ámbito de aplicación del Reglamento (UE) 650/2012, pero añadiendo un precepto en el que se indique que los certificados sucesorios nacionales quedarán regulados por las normas de producción interna; c) la inclusión en el ámbito de aplicación del Reglamento sucesorio de los certificados sucesorios nacionales, mediante una regulación específica, como la que ya existe para las certificados sucesorios europeos, y haber distinguido claramente las funciones o la finalidad de cada tipo de certificado; d) la inclusión en el ámbito de aplicación del Reglamento (UE) 650/2012 de los certificados sucesorios nacionales, mediante la eliminación de las normas de competencia de los certificados sucesorios europeos, con lo cual regirían las normas de competencia general para ambos tipos de certificados.

Esta última solución propuesta es la que, según los Gobiernos alemán y portugués, en el asunto Vincent Pierre Oberle, debería haberse realizado, si se hubiesen querido incluir los certificados sucesorios nacionales en el ámbito de aplicación del Reglamento (UE) 650/2012. No obstante, si se hubiese optado por esta opción, la inclusión del art. 64 del Reglamento sería superflua y tendría que eliminarse. Esto en la práctica, hubiera imposibilitado que se pudiese acudir a otras autoridades que, en virtud del Derecho nacional, fuesen competentes para sustanciar sucesiones mortis causa, como son los notarios, para la expedición de los certificados sucesorios europeos; sin que estos tengan que respetar necesariamente las normas de competencia internacional. Esto es así, si se sigue la línea interpretativa del art. 64 realizada por R. CRÔNE y P. WAUTELE, que como ya he reiterado, parece la más apropiada en atención a los objetivos del Reglamento (UE) 650/2012.

${ }^{219}$ P. Wautelet, “Chapitre VI: Certificat Successoral Européen” en A. Bonomi/P. Wautelet/I. Pretelli/A. Öztürk, Le droit européen des successions. Commentaire du Règlement $n^{o}$ 650/2012 du 4 juillet 2012, $2^{\mathrm{a}}$ ed., Bruylant, Bruxelles, 2016 , pp. 780-791; B. KreßE, “Chapter VI: European Certificate of Succession”, en A.-L. Calvo Caravaca/A. Davi/H.-P. Mansel (eds.), The EU Succession Regulation: a commentary, Cambridge University Press, Cambridge, 2016, pp. 680-685; D. Stamatiadis, "Chapter VI: European Certificate of Succession", en H. Pamboukis (ed.), EU Succession Regulation No. 650/2012: A Commentary, C.H. Beck/Hart Publishing, Oxford, 2017, pp. 590-593. 